\title{
A jawed polychaete fauna from the late Ludlow Kozlowskii event interval in the Prague Basin (Czech Republic)
}

\author{
Petra TONAROVÁ, MATS E. ERIKSSON \& OLLE HINTS
}

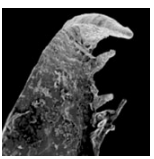

This paper deals with a diverse fauna of polychaetes possessing jaws (= scolecodonts) from the late Silurian Kopanina Formation of the Prague Basin (Czech Republic). The most common genera are Kettnerites, Oenonites and Pistoprion; the entire collection contains at least 16 genera. This is in stark contrast to the four genera recorded from this region by previous authors. The fauna described shows great similarities with coeval ones reported from the Baltic area (Gotland and Estonia), Siberia, Arctic Canada and the British Isles. These new data thus extend the palaeobiogeographical and palaeolatitudinal distribution of several taxa, particularly at the genus but also the species level. The sampled interval embraces the Kozlowskii event and its effects on the polychaetes are briefly discussed. Although the collections are relatively small, particularly from post-event strata, a faunal reorganisation is apparent. The studied collection enabled the stratigraphical ranges of some taxa, including tretoprionids and possibly polychaeturids, to be extended into the late Ludlow. One new species, "Mochtyella" pragensis, is described. - Key words: scolecodonts, palaeobiogeography, Kozlowskii/Lau event, Silurian, Ludlow, Kopanina Formation, Prague Basin.

TONAROVÁ, P., ERIKSSON, M.E. \& HINTS, O. 2012. A jawed polychaete fauna from the late Ludlow Kozlowskii event interval in the Prague Basin (Czech Republic). Bulletin of Geosciences 87(4), 713-732 (6 figures). Czech Geological Survey, Prague. ISSN 1214-1119. Manuscript received September 19, 2011; accepted in revised form March 27, 2012; published online May 3, 2012; issued October 17, 2012.

Petra Tonarová, Institute of Geology and Palaeontology, Faculty of Science, Charles University, Albertov 6, 12843 Prague 2, Czech Republic; Czech Geological Survey, Geologická 6, 15200 Prague 5, petra.tonarova@geology.cz. - Mats E. Eriksson, Department of Earth and Ecosystem Sciences, Lund University, Sölvegatan 12, SE-223 62 Lund, Sweden; Mats.Eriksson@geol.lu.se• Olle Hints, Institute of Geology at Tallinn University of Technology, Ehitajate 5, 19086 Tallinn, Estonia; Olle.Hints@gi.ee

Polychaete worms represent one of the most common components of benthic invertebrate faunas in the recent oceans and they have a world-wide distribution (e.g. Hutchings \& Fauchald 2000). Except for their jaws (= scolecodonts), chaetae and their associated tubes and burrows, polychaetes do not fossilize well as they are composed of soft tissue that generally decomposes rapidly. The fossil record of polychaetes dates back to the middle Cambrian (Conway Morris 1979, 1985), but the oldest undoubted scolecodonts are recorded from the latest Cambrian strata (Williams et al. 1999). Similarly as in modern-day oceans most Palaeozoic jaw-bearing polychaetes belong to the order Eunicida, representatives of which today live as infaunal burrowers, epifaunal crawlers, tube builders or inhabit reefs and reef-like structures (e.g. Paxton 2000). Just as their mode of life is variable, eunicidan feeding strategies are also diverse: carnivorous, herbivorous, omnivorous scavengers; some taxa use their jaws to excavate into coral frameworks and are thus efficient bioeroders (Paxton 2000). Similar modes of life and feeding strategies are expected also in deep time and their inferred behaviour may aid in reconstructing and understanding palaeoenvironments.

The complex eunicidan jaw apparatuses consist of a pair of ventral mandibles and a multi-element dorsal maxillary apparatus (e.g. Kielan-Jaworowska 1966, Szaniawski 1996). The maxillae are by convention numbered from posterior to anterior with an "M" and successive Roman numerals: MI-MVI. The paired maxillae are referred to left and right when viewed from the dorsal side. Their composition of resistant organic matter (scleroproteins) and hardening by various metals or other minerals (Michel \& DeVillez 1978) add to their fossilization potential.

Only a few reports have been published on Silurian scolecodonts from the Prague Basin (Žebera 1935, Bouček 1941, Šnajdr 1951, Tonarová 2008). One aim of the present paper is to compare results from historical collections, based on specimens preserved on bedding plane surfaces, with new samples from which scolecodonts were recovered 


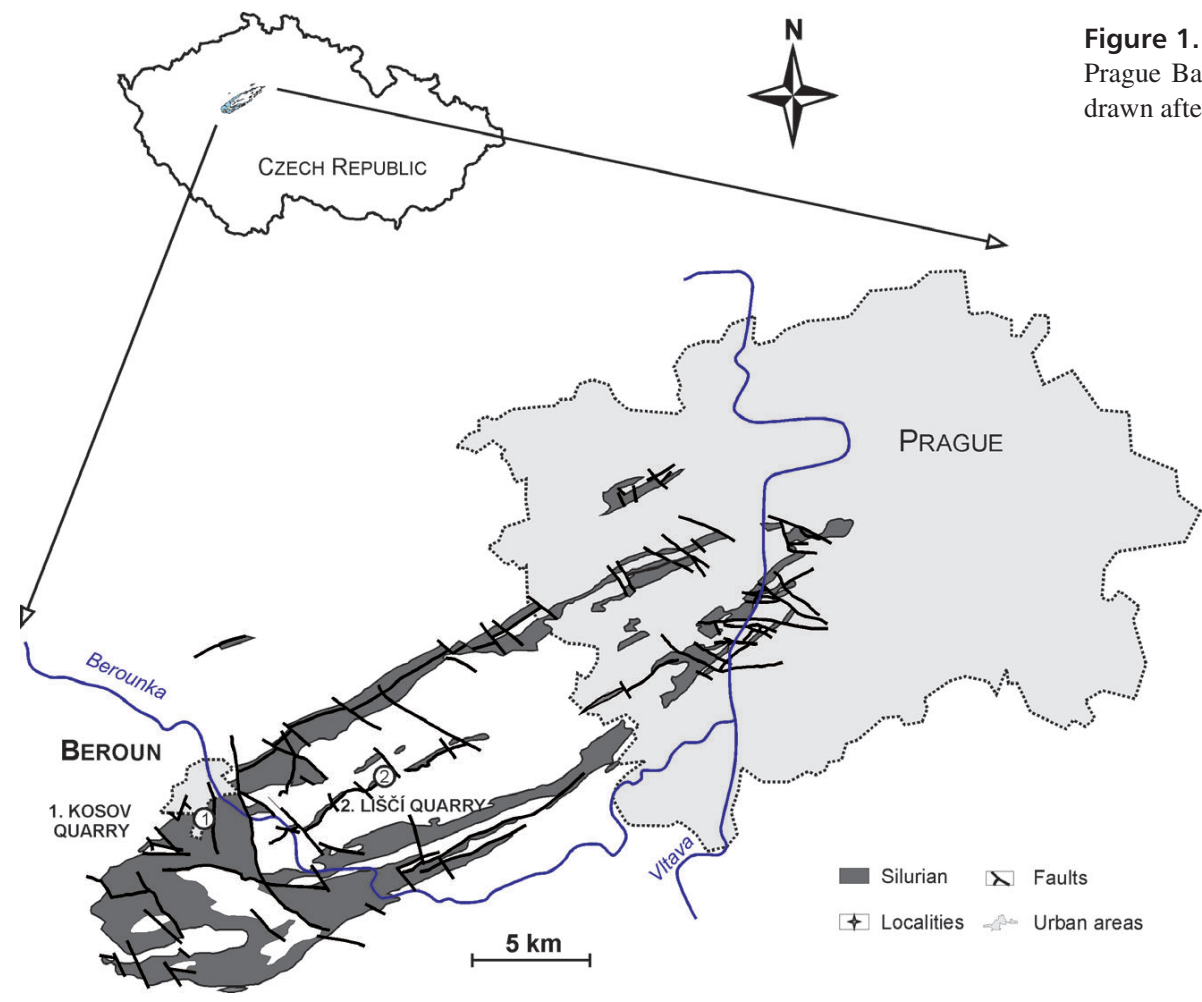

through acid digestion. As in the previous studies, the Ludfordian Kopanina Formation of the Liščí and Kosov quarries, Prague Basin, Czech Republic, was sampled. The stratigraphical interval spans the Neocucullograptus kozlowskii and Pseudomonoclimacis latilobus-Slovinograptus balticus graptolite biozones, thus also embracing the Kozlowskii event. Being the first account of a diverse scolecodont assemblage from Perunica, this work provides important information on the distribution, taxonomic composition and biogeography of Silurian polychaetes.

\section{Geological background}

The Prague Basin was defined by Havlíček (1981, 1982) for the Ordovician to Middle Devonian deposits situated between Prague and Pilsen. The study of these commonly richly fossiliferous rocks commenced more than 150 years ago (for summary see Chlupáč et al. 1998), which makes it one of the best studied early Palaeozoic basins. The entire Silurian succession is non-metamorphosed, with rich and diverse benthic and pelagic fossil faunas. It is confined, together with Devonian deposits, to the central part of the present synclinorium of the Prague Basin (Fig. 1). The gradual synsedimentary deformation accompanied by the strong submarine volcanism that culminated during the late Wenlock and early Ludlow, formed the character of the basin (Kř́̌ž 1991). The volcaniclastic accumulations gave rise to submarine elevations and also to an emergent island surrounded by shallow-water bioclastic limestone (Horný 1955, 1962; Kř́ž 1991). In general, the Silurian deposits originated in a relatively shallow, warm-water environment within the subtropical climatic zone (Kř́ǐ 1991, Štorch et al. 2006).

The present study is focused on a succession of the Kopanina Formation (late Ludlow) that is composed of cephalopod and brachiopod-rich limestones, dark platy micritic and biomicritic limestone, calcareous shale, tuffaceous limestones, and calcareous tuffs (Horný 1955; Kukal 1955a, b; Kříž 1991, 1992; Ferretti \& Kříž 1995; Čáp 2002; Čáp et al. 2003). This succession has recently been investigated for graptolite biostratigraphy (Štorch 1995) and the Kozlowskii event (Manda \& Kříž 2006, Lehnert et al. 2007, Manda et al. 2012).

The Kosov and Lišči quarries were chosen for this study on the basis of previous reports on scolecodonts by Žebera (1935) and Šnajdr (1951). The latter author described the Lišči Quarry as the richest locality for scolecodonts in the Prague Basin, even though he dealt only with shales from the upper part of the Kopanina Formation. The localities and regional history of scolecodont research are briefly described below.

\section{The Kosov Quarry}

The Kosov Quarry is situated in the western segment of the Prague Basin (sensu Kř́̌ž 1991) approximately 1.5 km 
southwest of the city of Beroun (see Fig. 1), on the northwestern slope of the Kosov Hill (= "Dlouhá hora"). The sequence of Silurian rocks exposed in this quarry starts with the Motol Formation (Wenlock Series, middle Sheinwoodian) and reaches the middle part of the Přídolí Formation (Přídolí Series) (Horný 1955, Kř́̌̌ 1992).

The studied section $\left(49^{\circ} 56^{\prime} 22.0^{\prime \prime} \mathrm{N}, 14^{\circ} 03^{\prime} 16.2^{\prime \prime} \mathrm{E}\right.$, Fig. 2A) is situated on the second level of the southern part of the Kosov Quarry area. Detailed information on this exposure is provided by Kříž (1992), Štorch (1995) and Lehnert et al. (2007, p. 233, figs 4-6), who documented fossil groups such as graptolites and conodonts, facies architecture and the stable isotope $\left(\delta^{18} \mathrm{O}, \delta^{13} \mathrm{C}\right)$ record. The studied scolecodont samples derive from beds 2 to 19 sensu Lehnert et al. (2007). The upper part of the Kopanina Formation (Ludfordian Stage) exposed in this section corresponds to the N. kozlowskii and P. latilobus-S. balticus graptolite biozones. By comparison, Šnajdr's (1951) scolecodont samples were collected from several shale beds within the P. latilobus-S. balticus and Pristiograptus fragmentalis biozones.

Unfortunately, conodonts are represented mainly by long-ranging coniform taxa, with the exception of bed 10 , in which the index species Polygnathoides siluricus is present (Lehnert et al. 2007; L. Slavík, Prague, personal communication 2010). The lower part of the section represents relatively deeper-water settings of the transition from the lower slope of the Kosov volcanic complex to the basin. It is composed of deep-water shales, tuffitic shales and black spiculitic mud- to wackestone. Upwards through the section the shale content decreases and the environment becomes relatively shallower with strata represented by bioclastic wackestone and packestone (Lehnert et al. 2007). The trends in changes of the environment are supported also by previous macrofaunal studies (e.g. Kř́žz 1992).

\section{The Lišči Quarry}

The Liščí Quarry (Fig. 1) is situated in the central segment of the Silurian sedimentary area of the Barrandian (sensu Kříz 1991) and it is a component of the "Amerika anticline" (Svoboda \& Prantl 1954). The quarry is situated approximately $2 \mathrm{~km}$ northwest of Karlštejn Castle and about $2 \mathrm{~km}$ west of the Mořina village. The quarry and its surroundings have been studied since the first half of $20^{\text {th }}$ century (for details see Horný 1955; Kř́žz 1986, 2008, and references therein). This locality is one of the richest in terms of Silurian fossils from the Prague Basin with more than 200 species hitherto reported (Kř́̌̌ 2008). The Kopanina Formation exposed in the quarry comprises several lithotypes varying in the amount of tuffite material, colour and proportion of bioclasts (Kukal 1955b, Mikuláš et al. 2003).
The studied section $\left(49^{\circ} 57^{\prime} 18^{\prime \prime} \mathrm{N}, 14^{\circ} 10^{\prime} 23^{\prime \prime} \mathrm{E}\right)$ is located in the north-western part of the quarry. The scolecodont samples derive from eight levels representing the upper part of the $P$. siluricus conodont Zone (L. Slavík, Prague, personal communication 2010), corresponding to the Acanthalomina minuta Community (Horný 1955). The rocks are predominantly bioclastic light to dark grey wackestone and packestone with intercalations of grey tuffitic shale (see simplified profile in Fig. 2B).

\section{Material and methods}

Twenty-six samples were processed in the palynological laboratory of the Faculty of Science, Charles University in Prague. All samples yielded scolecodonts, sometimes accompanied also by chitinozoans, sponge spicules, brachiopods, graptolites and unidentifiable organic fragments. The weight of the initial bulk samples varied from 200 to $1000 \mathrm{~g}$. Generally only up to $200 \mathrm{~g}$ was dissolved using a methodology similar to that described in detail by KielanJaworowska (1966), but with an acetic acid concentration of $5 \%$. Sample processing took approximately one month, including changing of acid and sieving the samples every week. Particularly resistant samples were subsequently treated with $20 \%$ hydrochloric and $30 \%$ hydrofluoric acid. After digestion the residue was gently rinsed through a $50 \mu \mathrm{m}$ sieve. Finally, the wet samples were hand-picked from Petri dishes under a stereomicroscope, using a micropipette or an eyelash. Some specimens still had to be cleaned in hydrogen peroxide or hydrofluoric acid depending on the character of adherent particles. The specimens are stored in small plastic containers filled with glycerine and a drop of formaldehyde to prevent mould growth.

The specimens were photographed using a Scanning Electron Microscope (SEM): a JEOL JSM-6380 at the Institute of Geology and Palaeontology (Charles University in Prague), Hitachi S-3400N at the Department of Earth and Ecosystem Sciences (Lund University) and Zeiss EVO MA15 at the Institute of Geology (Tallinn University of Technology). Additional photographs were taken with a digital camera attached to a Nikon AZ100 light microscope in Tallinn. All samples are stored in the collections of the Czech Geological Survey under numbers PT1 to PT27. Scolecodont descriptive terminology follows that of Kielan-Jaworowska (1966).

\section{Scolecodonts from the Prague Basin}

\section{Previous records}

The first, but also the most disputable, remark on the occurrence of scolecodonts in the Prague Basin is that by Perner 
(1894). He found a "conodont", Prioniodus barrandei Perner, 1894, in the Silurian rocks of the "Lapworth Colony", subsequently correlated with the Telychian Streptograptus crispus graptolite Biozone by Štorch (1994). Perner supposed that his specimen was of polychaete affinity and noted its resemblance to the extant genus Staurocephalus Grube, 1855. He used the designation "conodont" merely because the term scolecodont was not coined until considerably later, by Croneis \& Scott (1933). Žebera (1935) who probably had this material at his disposal, later interpreted the specimen as a conodont and compared it to his species Prioniodus perneri Žebera, 1935. Although this interpretation most probably was correct the type material of $P$. barran$d e i$ cannot be located at present, thus further re-evaluation is not possible.

The first detailed study of scolecodonts was by Žebera (1935), who sampled three Silurian localities exposing strata of the P. latilobus-S. balticus and N. ultimus graptolite biozones. Žebera recovered more than 150 specimens and established nine new species: Arabellites perneri, A. angustidens, A. innaequidens, A. kettneri, Ebetallites ancoraeformis, Kettnerites kosoviensis, K. depressus, Pernerites giganteus and Pronereites naviculiformis. The most common species in the collection is the one he assigned to A. perneri, followed by Pernerites amplus (the latter was, however, not mentioned in his published paper). The labels in the collection seem to have been prepared for further work that was never completed. Some of the specimens from the Amerika quarries (Liščí Quarry, Mořina area) are closely similar to A. perneri but were designated $K$. kosoviensis, indicating that Žebera intended such a reassignment. The collection of Žebera (1935) is housed in the Institute of Geology and Palaeontology, Charles University in Prague under the numbers IGP coll. Žebera 1-154 (not all specimens are present) and at the National Museum in Prague under the number 28368.

Šnajdr (1951) reassigned most of Žebera's taxa to Kettnerites kosoviensis Žebera, 1935. The main reason for this was that Šnajdr considered their differences to reflect intraspecific variability. Using the approach of Bergman (1989), the Šnajdr collection would consist of two or three species of Kettnerites but the preservation of the specimens does not allow more detailed assessment. The two remaining species of Žebera, Ebetallites ancoraeformis and Pernerites giganteus, together with Ildraites? budñanensis Šnajdr, 1951, are of non-paulinitid affinity and need taxonomic revision. Šnajdr obviously was aware that additional species occurred in the samples but left them in open nomenclature or undescribed until it would be possible to match them to apparatus-based species. He worked mainly with specimens that were preserved in associated clusters on the bedding plane surfaces, in order to determine what different types of elements were included in one species.
Šnajdr (1951) also emended the diagnosis of Kettnerites Žebera, 1935. Unfortunately his study did not include examination of Žebera's original collection but instead he supported the results on his own extensive collections, which consist of several thousand bedding plane specimens from the same stratigraphical interval. Less than one hundred of these specimens belong to genera other than Kettnerites, but their proper determination is complicated due to their poor preservation.

The collection of Šnajdr (1951) is presently housed at the National Museum in Prague under collection numbers 32921, 32984 and 32983. For additional information on the historical collections, see Tonarová (2008).

Žebera (1935) and Šnajdr (1951) did not dissolve rocks from the Prague Basin for the recovery of isolated jaws, which generally are essential for accurate taxonomic determination. Despite the remarkable amount of material gathered, the bedding plane specimens are commonly compacted and/or cracked which obviously hampers identification. An attempt by the present authors at dissolving slabs with visible scolecodonts yielded residues with only poorly preserved, usually fragmentary, specimens of little taxonomic value. Therefore, different lithologies and stratigraphical intervals were chosen for this study.

The lower diversity recorded from shale levels in the Prague Basin compared to most of the limestone digested in this study (see below) most likely result from differences in environmental, depositional and/or taphonomical factors, however, the precise interrelationship of which remains to be addressed more closely in the future.

\section{The polychaete fauna of the Kopanina Formation}

The new collection comes mainly from the N. kozlowskii and $P$. latilobus-S. balticus graptolite biozones. Unlike the previous shale samples of Žebera and Šnajdr, we have focused on limestones in order to recover more threedimensionally preserved specimens. Altogether the studied collection contains several thousand scolecodonts, including approximately 1100 first and second maxillae. In addition, eight fused jaws and/or semi-articulated tiny maxillary apparatuses (some possibly juveniles) were recovered. Twenty-five different species were identified, not including several unknown jaws that at the present time cannot be reconstructed into apparatuses due to their insufficient number and/or poor preservation. This particularly concerns forms with placognath type apparatuses. The apparatus reconstructions of placognaths are often complicated since different taxa may have certain elements in the apparatus that are virtually indistinguishable. Thus, the actual number of species is estimated to exceed 25 . 
A

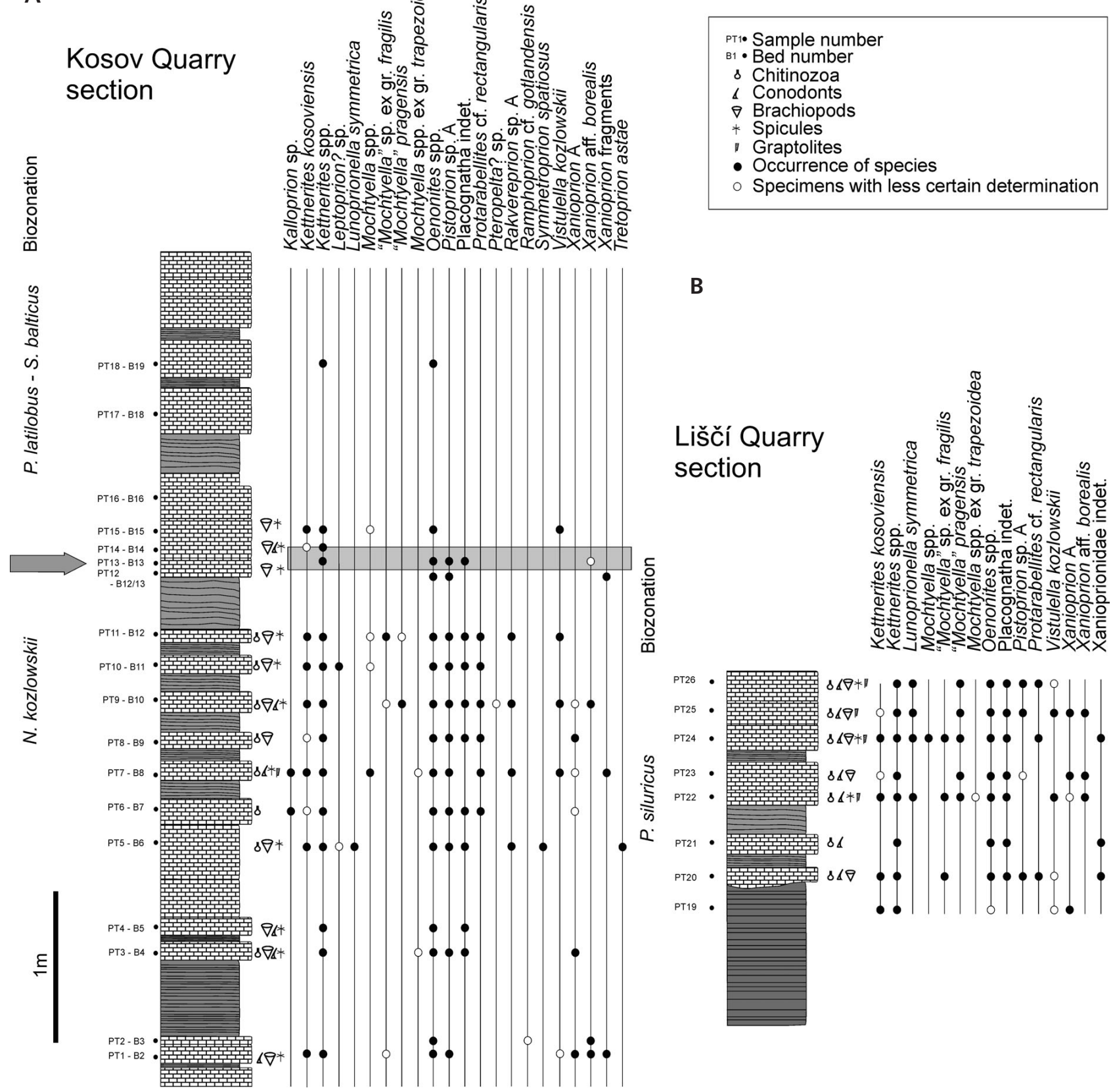

Figure 2. Distribution of scolecodonts in the Kosov and Liščí quarries. • A - the Kosov Quarry section; the lithological column, including bed numbers (B2, etc.), follows Lehnert et al. (2007). Arrow pointing to the Kozlowskii event and beginning of the $\delta^{13} \mathrm{C}$ excursion. $\bullet B-$ the Lišči Quarry section.

The yield reaches approximately 800 posterior maxillae per kg of rock in the richest sample (PT7), and ranges from 10 to 400 per $\mathrm{kg}$ in other productive samples. These are similar or slightly lower numbers than generally reported from the Silurian of Baltica (e.g., Eriksson et al. 2004, Hints et al. 2006).

The fauna is dominated by polychaetaspids and paulinitids, followed by mochtyellids and xanioprionids. Ramphoprionids are less common, and only rare specimens of tetraprionids, kalloprionids, symmetroprionids and tretoprionids have been found. The polychaete fauna of both quarries is, with few exceptions, closely similar. In the Kosov Quarry the diversity is slightly higher and includes representatives of Kalloprion Kielan-Jaworowska, 1962, Leptoprion Kielan-Jaworowska, 1966, Rakvereprion Mierzejewski, 1978 and Symmetroprion KielanJaworowska, 1966 that were not recorded in the Liščí Quarry. This could, however, be attributed also to the 
greater stratigraphical extent of sampled strata (and more samples) in the former section. The uppermost part of the Kosov Quarry section is composed of gravity flow sediments that yielded only fragmentary scolecodonts, of which only Kettnerites Žebera, 1935 and Oenonites Hinde, 1879 could be identified. The preservation in general is better in Liščí Quarry due to lithologies and/or post-depositional conditions that apparently did not cause flattening and deformation of the specimens. Similarly, conodonts including both platform and coniform forms are better preserved and more abundant in Liščí Quarry. The distribution of taxa is shown in Fig. 2 and selected characteristic forms are illustrated in Figs 3-6. Individual taxa are discussed further below.

\section{The Kozlowskii/Lau event and its influence on the polychaete faunas}

The Ludfordian (late Silurian) environmental and biological crisis known as Lau and/or Kozlowskii event (for Lau and Kozlowskii event correlation problems, see Manda et al. 2012 and references therein) has received increasing attention since the introduction of the Lau event by Jeppsson (1993) and Kozlowskii event by Urbanek (1993). This is not surprising considering that the event is associated with the largest positive carbon isotope excursion of the Phanerozoic (Lehnert et al. 2003, Munnecke et al. 2003), dramatic faunal turnovers (see summary in Jeppsson \& Aldridge 2000, Calner 2008) and collapse of the marine ecosystem (Calner 2005). Profound biotic changes have been recorded, e.g., among conodonts (Jeppsson \& Aldridge 2000), acritarchs (Stricanne et al. 2006), graptolites (Urbanek 1993, Štorch 1995, Melchin et al. 1998, Manda et al. 2012), cephalopods (Manda 2008) and fish (Eriksson et al. 2009). Barrick et al. (2010, p. 32), on the other hand, recorded "normal ecological adjustments to environmental changes" rather than major extinctions and ecosystem collapse, although, as noted by those authors, based on limited faunal data. Similarly Slavík et al. (2010) recorded moderate changes in the conodont fauna of the Prague Basin, incomparable to those changes recorded in Gotland, Sweden, or Australia. According to Manda \& Kř́̌ž (2006) also pelagic orthocerids and the nektonic Ceratiocaris passed unaffected through the critical interval.

Jeppsson \& Aldridge (2000, p. 1144), referring to Bergman (1989), were the first ones to interpret changes in polychaete faunas as a response to Lau event. Bergman (1989) recorded gradual faunal changes in the Hemse-Eke interval on Gotland. Later, Eriksson et al. (2004) concluded that approximately one-third of the polychaete taxa on Gotland went extinct during the event and also reported some lineages with Lazarus gaps. Eriksson \& Frisk (2011) noted that the environmental changes linked to the Lau event did not seem to have affected polychaetes as profoundly as planktic and nektic organisms such as graptolites, fish and conodonts.

In this study only the Kosov Quarry section records the event interval (Fig. 2, Manda et al. 2012). With the beginning of the carbon isotope excursion (based on $\delta^{13} \mathrm{C}$ data of Lehnert et al. 2007) the number of polychaete genera decreases from 15 to 4, and only Kettnerites spp., Oenonites spp. and Vistulella kozlowskii Kielan-Jaworowska, 1961 were recorded in the beds above the LAD of N. kozlowskii in bed No. 15. In overlying strata only Kettnerites spp. and Oenonites spp. occur (Fig. 2A), which indicates a dramatic decrease in polychaete diversity across the event. However, it should be kept in mind that the studied succession is stratigraphically restricted and only a limited number of samples represent post-event strata (including the graptolite recovery interval of the Kozlowskii event sensu Manda et al. 2012). Moreover, those latter few samples come from gravity flow deposits (turbidites or tempestites according to Lehnert et al. 2007), where only fragmentary scolecodonts (Kettnerites spp. and Oenonites spp.) were found. Thus, it cannot be excluded that the lack or rarity of scolecodonts in these beds represents a taphonomical bias.

Nonetheless, K. kosoviensis re-appears at least in the shale above this interval, indicating an uninterrupted range through the entire succession, or a reintroduction once environmental conditions stabilized. In addition, some species (e.g., Protarabellites rectangularis Eriksson, 2001, Kettnerites sisyphi Bergman, 1989, various species of Oenonites) have been reported from stratigraphically younger beds elsewhere (Hints 1998, Eriksson 2001), showing that they did not become extinct. On the other hand, Pistoprion Kielan-Jaworowska, 1966, which is very common in pre-event strata, has not been reported from the latest Silurian or Devonian (except for a questionable identification by Jansonius \& Craig 1972). Although our data suggest a faunal reorganisation, it is obvious that detailed, high resolution studies, preferably also from different regions, are needed in order to resolve precisely how the Kozlowskii/Lau event affected polychaetes.

\section{Palaeobiogeographical significance}

Several new reports on Silurian scolecodonts have been published over the last few decades: for an overview, see Eriksson et al. (2004). More recently, Hints \& Eriksson (2007a, b) and Eriksson et al. (in press) discussed the biogeographical patterns of Silurian (and Ordovician) polychaete genera, stressing a strong sampling bias: the majority of the material comes from Baltica, especially Sweden and Estonia, as well as from erratic boulders found in Poland. Some data derive also from Avalonia and Laurentia, 
whereas the Gondwanan realm is scarcely studied. Therefore the collection from the Prague Basin described herein, representing a part of the peri-Gondwanan microcontinent Perunica (Havlíček et al. 1994), is important for understanding the global biogeographical patterns of polychaetes during the Silurian.

The previously known Silurian polychaete assemblages (Eriksson et al. 2004; Hints \& Eriksson 2007a, b; Eriksson et al. in press) are generally similar to those of the Late Ordovician. They are commonly dominated by polychaetaspids, paulinitids and mochtyellids (e.g., Oenonites; Kettnerites; Mochtyella Kielan-Jaworowska, 1961; Pistoprion; Vistulella Kielan-Jaworowska, 1961), whereas ramphoprionids, atraktoprionids, kalloprionids, symmetroprionids and others may also be present, albeit generally considerably less abundantly. Some genera, for instance Symmetroprion, Skalenoprion Kielan-Jaworowska, 1966, Langeites Kielan-Jaworowska, 1966 and Lanceolatites Bergman, 1987 occur primarily in the Silurian, and only a few taxa typical of the Ordovician, such as polychaeturids in the Baltic faunas, are rare or missing in the Silurian. Previous reports on the palaeobiogeography of polychaetes have shown that they, like most other groups of fossils (e.g. Armstrong \& Owen 2002), display a decrease in endemism from the Ordovician to the Silurian (Hints \& Eriksson 2007a, b; Eriksson et al. in press).

The late Silurian Prague Basin fauna is characterized by an overall dominance of paulinitids, polychaetaspids and mochtyellids, which is consistent with the most abundant and diverse families in Baltica (Eriksson et al. 2004, Eriksson 2006). It is noteworthy that none of the genera identified appears to be endemic to the Prague Basin. However, several taxa that are common elsewhere, particularly in Baltica, were not recorded in the studied collection. For instance, paulinitids are represented only by Kettnerites, whereas additional genera are reported from approximately coeval strata from other regions (Bergman 1989, Eriksson et al. 2004). Similarly, Kozlowskiprion Kielan-Jaworowska, 1966 and other polychaetaspid genera (except for Oenonites) known from Gotland (Eriksson 1997, 1998) have not been recorded in the Prague Basin thus far. A particular feature of the present collections is also the scarcity of atraktoprionids and skalenoprionids, both of which are sometimes abundant in the Baltic region (e.g., Eriksson 2006; note, however, that a few atraktoprionid jaws were recorded in Šnajdr's bedding plane collections). The relatively lower diversity, compared to Baltic faunas, can probably be attributed to the limited size and restricted stratigraphical and environmental range of the Bohemian collections. Additional genera, also in common with other regions, will most likely be recorded when more material becomes available.

Notwithstanding this, the present collection represents the most diverse Silurian polychaete fauna from Gondwana/peri-Gondwana and several families (and genera) are identified from this area for the first time. These include symmetroprionids, tetraprionids, tretoprionids and ramphoprionids. Eriksson (2002) noted that ramphoprionids were not recorded from Gondwana and peripheral areas and that their known occurrences indicated that they were confined to near equatorial latitudes during the Silurian. The new Prague Basin findings of Protarabellites Stauffer, 1933 and Ramphoprion Kielan-Jaworowska, 1962 extend the distribution of ramphoprionids and reveal additional faunal similarities with Baltica.

Similarities of the Bohemian faunas with those known from Baltica, Laurentia and Siberia are noted also at the species level. Findings of Pistoprion sp. A, Vistulella kozlowskii, Symmetroprion spatiosus (Hinde, 1882), Ramphoprion cf. gotlandensis Eriksson, 2001, Protarabellites cf. rectangularis Eriksson, 2001 and Kettnerites cf. sisyphi suggest a wide, possibly cosmopolitan, distribution of these species in the late Silurian. Other species recorded previously from the Baltic region only (e.g., Tretoprion astae Hints, 1999) appear now to have had a wider distribution.

In most palaeogeographical reconstructions there is an agreement that Baltica and Laurentia (Laurussia) were located close to the palaeoequator during the late Silurian and represented by tropical to subtropical environments (e.g. Torsvik et al. 1992, Cocks \& Torsvik 2002). The position of Perunica is less well constrained, but according to Tait $e t$ al. (1997), Cocks \& Torsvik (2002) and Fatka \& Mergl (2009) it was situated in more temperate climates in the peri-Gondwanan area at $c a 30^{\circ} \mathrm{S}$. Havlíček (1999) argued, based on benthic faunas (brachiopods, trilobites and other fossils), that Perunica was much closer to Baltica than any other region of Gondwana, specifying its position to the northeastern corner of peri-Gondwana. A similar palaeogeographic scenario is suggested from the faunal distribution of nautiloid cephalopods (Stridsberg 1985; Stridsberg \& Turek 1997; Manda 2007, 2008; Turek \& Manda 2011) and particularly shallow water bivalves (Kříž 1999, 2008). This study also supports close faunal links between Perunica and Baltica and, at least for jawed polychaetes, there seem to have been few climatic or other palaeobiogeographical barriers between these palaeocontinents. Moreover, the new Bohemian collection corroborates the idea of most polychaete genera and many species being geographically wide spread during the Silurian (Hints \& Eriksson 2007a, b; Eriksson et al. in press).

\section{Systematic palaeontology}

Phylum Annelida Lamarck, 1809

Class Polychaeta Grube, 1850

Order Eunicida Dales, 1963

Superfamily Eunicea Grube, 1852

Family Mochtyellidae Kielan-Jaworowska, 1966 


\section{Genus Mochtyella Kielan-Jaworowska, 1961}

Type species. - Mochtyella cristata Kielan-Jaworowska, 1961.

\section{"Mochtyella" pragensis sp. nov.} Figure $3 \mathrm{~A}-\mathrm{S}$

Holotype. - Right MI (Fig. 3C, D), from sample PT23, specimen number PT27.1, Liščí Quarry.

Type horizon and locality. - Liščí Quarry, Prague Basin, Kopanina Formation, Ludfordian (upper Silurian).

Material. - 12 right MI, 13 left MI.

Etymology. - The specific name refers to the Prague Basin, the location of the species.

Diagnosis. - "Mochtyella" pragensis is tentatively assigned to Mochtyella but differs from the typical species of the genus by its characteristically fragile maxillae, which are similar to those of M. fragilis and M. grazynae. It differs from $M$. fragilis in having longer, more prominent and more anteriorly placed second ridge in right MI, and posteriorly protruding laeobasal ridge in left MI. “M." pragensis differs from M. grazynae also in having anteriorly curved main ridges instead of straight ones.

Description. - Both first maxillae are compound jaws of approximately the same length. Except for the black or dark brown denticulated ridges the jaws are almost translucent, composed of yellowish-brown thin membrane.

Right MI is longitudinally elongated and provided with three denticulated ridges, with a typically cordate anterior part. The length is $280-410 \mu \mathrm{m}$, the width $110-150 \mu \mathrm{m}(0.3-0.5$ of jaw length). In dorsal view the anterior part of the main ridge is almost right-angled. It is composed of 15 to 18 denticles, gradually decreasing in size posteriorly. The second ridge encompasses the left anterior part of the main ridge, forming a semi-arch, ending almost in the middle of the jaw. Its length is 80-220 $\mu \mathrm{m}$ (0.4-0.6 of jaw length). The denticulated basal ridge is situated on the right side of the main ridge but is quite commonly broken off. It is straight, parallel with the posterior part of the main ridge. Its length is 80-115 $\mu \mathrm{m}$ ( 0.3 of jaw length). In ventral view there is a gaping pulp cavity with three ridges that are distinctly separated.

Left MI is longitudinally elongated with two denticulated ridges, sometimes accompanied by a secondary ridge. The overall shape is suboval, in the anterior part almost rectangular. The length is $285-450 \mu \mathrm{m}$, the width $110-225 \mu \mathrm{m}(0.3-0.5$ of jaw length). The main ridge is composed of 14 to 17 denticles, decreasing in size posteriorly. In dorsal view the main ridge is in the anterior part almost right-angled. The laeobasal ridge is attached to the left side of the main ridge. It is straight, parallel to the posterior part of the main ridge, filling the space delimited by the flexure, and ending a little beyond the main ridge. The length of the laeobasal ridge is 154-290 $\mu \mathrm{m}$ (0.4-0.6 of jaw length). The length of the second ridge, if present, is 123-154 $\mu \mathrm{m}(0.35-0.4$ of jaw length). In ventral view there is a gaping pulp cavity, noticeably subdivided into two parts (main and laeobasal ridge).

Remarks. - This species belongs to the same group of taxa as M. fragilis Szaniawski, 1970 and M. grazynae Mierzejewski, 1978. The outline of their jaws, characteristic laeobasal ridges, and the "fragile" form of the jaws differ from those of typical Mochtyella (including the type species M. cristata and also M. polonica), suggesting that they may represent a separate mochtyellid genus. Since the latter still awaits formal description, we assign the new species to "Mochtyella".

Figure 3. Light microscopy images of selected scolecodonts showing the colours and thin membranes, to be compared with SEM micrographs. All specimens are in dorsal view, except possibly Z, AB, AD and AE, that may be in lateral view. Scale bars correspond to $100 \mu \mathrm{m}$. • A-S - "Mochtyella" pragensis n. sp. A, B - right MI No. PT27.2 from sample PT23, Liščí Quarry. C, D - right MI No. PT27.1 (holotype) from sample PT23, Liščí Q. E - right MI No. PT23E.1 from sample PT23, Liščí Q. F - right MI No. PT22H.1 from sample PT22, Lišči Q. G, H - same specimen, left MI No. PT27.3 from sample PT22, Liščí Q. I, J - left MI with broken laeobasal ridge (=lb ridge) No. PT27.4 from sample PT22, Liščí Q. K - left MI No. PT27.5 from sample PT22, Liščí Q. L - left MI with broken lb ridge No. PT27.6 from sample PT22, Liščí Q. M - left MI No. PT26D.1 from sample PT26, Liščí Q. N - left MI with broken lb ridge No. PT27.7 from sample PT22, Liščí Q. O - right MI No. PT24D.1 from sample PT24, Liščí Q. P - right MI No. PT25G.1 from sample PT25, Liščí Q. Q - left MI No. PT25G.2 from sample PT25, Liščí Q. R - left MI with broken lb ridge No. PT24D.2 from sample PT24, Liščí Q. S - left MI No. PT22F.1 from sample PT22, Liščí Q. • T, U - Mochtyella sp. ex gr. fragilis Szaniawski, 1970. T - left MI No. PT25G.5 from sample PT25, Liščí Q. U - left MI No. PT24D.3 from sample PT24, Liščí Q. • V - Mochtyella sp. ex gr. trapezoidea Kielan-Jaworowska, 1966, left MI No. PT22F.2 from sample PT22, Liščí Q. • W, X - Vistulella kozlowskii Kielan-Jaworowska, 1961. W - broken piece No. PT22F.3 from sample PT22, Liščí Q. X-part of an apparatus No. PT25G.3 from sample PT25, Liščí Q. • Y - carriers of a polychaetaspid No. PT26A.1 from sample PT26, Liščí Q. • Z - Lunoprionella symmetrica Eisenack, 1975, No. PT24D.4 from sample PT24, Liščí Q. • AA - Leptoprion? sp., right MI No. PT10B.1 from sample PT10, Kosov Q. - AB - Rakvereprion sp. A?, basal plate No. PT25G.4 from sample PT25, Liščí Q. • AC - Tretoprion astae Hints, 1999, right MI No. PT5D.1 from sample PT5, Kosov Q. AD, AE - Lunoprionella symmetrica Eisenack, 1975. AD - No. PT26D.2 from sample PT26, Liščí Q. AE - No. PT25G.6 from sample PT25, Liščí Q. 
Petra Tonarová et al. • A jawed polychaete fauna across the late Ludlow Kozlowskii event interval (Prague Basin)

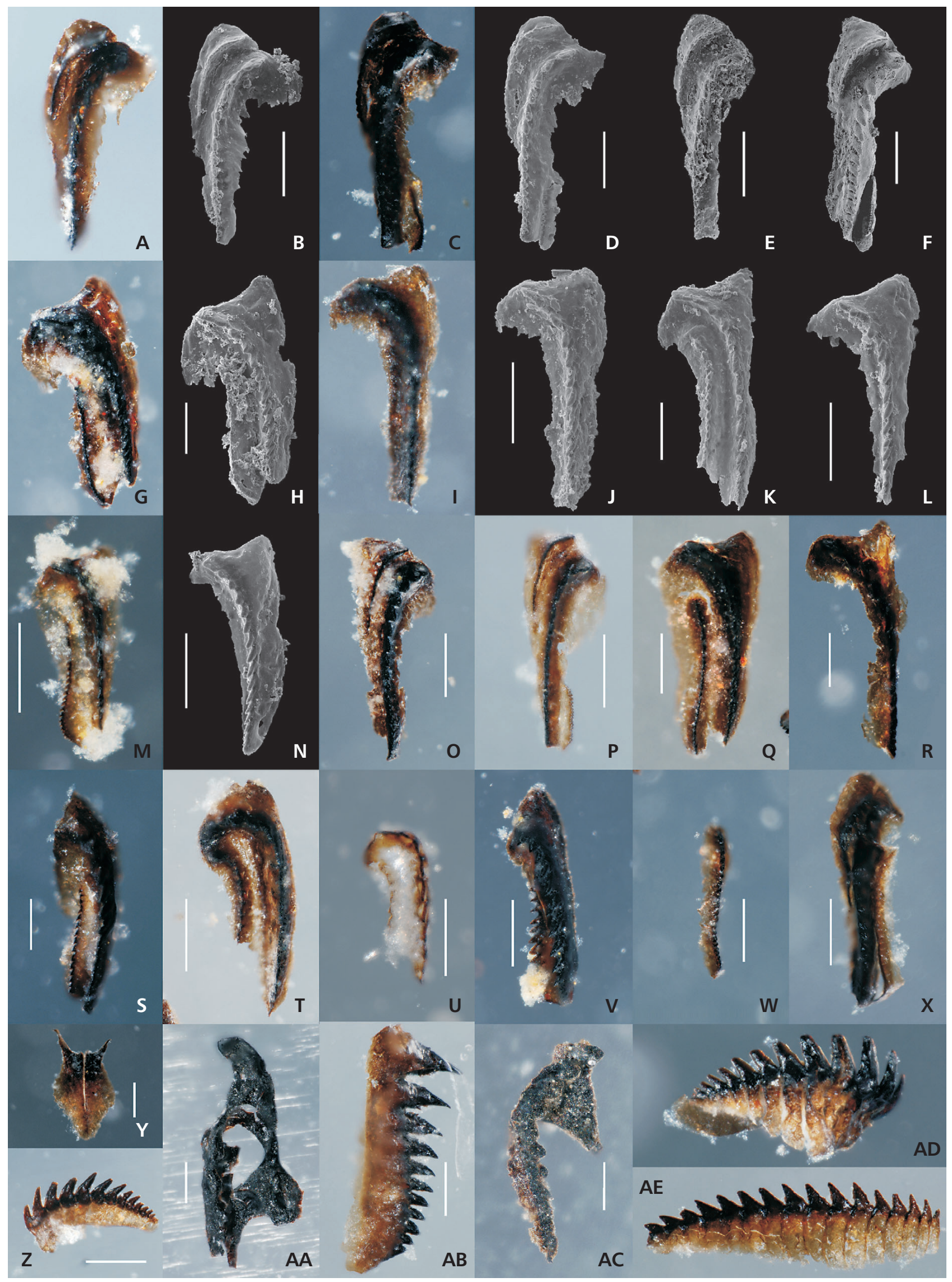


"Mochtyella" pragensis is most similar to "Mochtyella" sp. D of Hints et al. (2006, pl. 2:3) from the uppermost Llandovery of Estonia. It differs from the latter in having a longer second ridge and laeobasal ridge. Eller (1963, p. 175, pl. 1, figs 15-17) described a similar form from the Devonian Dundee limestone of the Sibley and Dundee quarries (Michigan) under the name Starocephalites ejectus. It possesses a similar second ridge but the laeobasal ridge seems to be broken. There are some additional species of Eller assigned to Staurocephalites Hinde, 1879, that are quite similar to "M." pragensis but type collection studies are necessary for more detailed assessments.

Occurrence. - Liščí and Kosov quarries, late Ludfordian, Silurian.

\section{Annotated list of taxa}

In the following list, selected characteristic taxa are briefly discussed. Some specimens could be determined only to genus level or higher, because of their poor preservation.

\section{Family Mochtyellidae Kielan-Jaworowska, 1966}

Discussion. - Mochtyellids generally are abundant in Silurian strata (Eriksson et al. 2004). In the Prague Basin Pistoprion Kielan-Jaworowska, 1966 dominates, but Vistulella Kielan-Jaworowska, 1961 is also relatively common. The genus Mochtyella sensu lato is represented mainly by specimens of the $M$. fragilis group; only a few specimens of $M$. polonica group and questionable specimens of $M$. trapezoidea group are present. The identification of mochtyellids has, to some extent, been hampered by preservation. Thus many fragmented specimens were classified merely as Placognatha indet. (Figs 2, 4V, Y).

\section{Genus Mochtyella Kielan-Jaworowska, 1961}

Mochtyella sp. ex gr. fragilis Szaniawski, 1970 (Figs 3T, $\mathrm{U}, 4 \mathrm{E}$ ) occurs in several samples from both sections studied, and sometimes together with "M." pragensis (see above). It has a thin and translucent jaw wall, darker large denticles on the main ridges of both MI, and a long laeobasal ridge. It is most similar to $M$. fragilis, but differs in lacking the second ridge on the right MI. Both this species and $M$. fragilis differ considerably from the type species of Mochtyella and therefore the present generic assignment is tentative. Mierzejewski (1978, p. 275) argued that mochtyellids possessing no second ridge cannot be assigned to Mochtyella. Here, however, we consider that the presence/absence of secondary ridge may be a species rather than genus level character within some groups of taxa.

Mochtyella sp. ex gr. polonica Kielan-Jaworowska, 1966 (Fig. 4C). This species or group of species is quite rare but some specimens might have been missed because of their poor preservation.

"Mochtyella" pragensis sp. nov. (Fig. 3A-S) occurs in both the Liščí and Kosov quarries. See the systematic description and further discussion above.

Mochtyella sp. ex gr. trapezoidea Kielan-Jaworowska, 1966 (Figs 3V, 4B). Only a few questionable specimens are present in samples PT3, PT7 and PT22. Even though specimens are recorded from both the Kosov and Liščí quarries, more precise determination is not possible due to their preservation.

\section{Genus Pistoprion Kielan-Jaworowska, 1966}

Pistoprion sp. A (Fig. 4K, L, N-R, U) is the most common taxon after Kettnerites and Oenonites in both sections

Figure 4. SEM micrographs of selected mochtyellids and xanioprionids. All specimens are in dorsal view, except M, V to X in lateral(?) view. Scale bars correspond to $100 \mu \mathrm{m}$, the first one for figures A to $\mathrm{O}$ and the second for $\mathrm{P}$ to $\mathrm{Z}$. Two scale bars are used because of the big difference in size of the specimens. - A - Mochtyella sp., part of an apparatus No. PT26H.3 from sample PT26, Liščí Quarry. • B - Mochtyella sp. ex gr. trapezoidea Kielan-Jaworowska, 1966, left MI No. PT27.10 from sample PT22, Liščí Q. • C - Mochtyella sp. ex gr. polonica Kielan-Jaworowska, 1966, left MI No. PT27.11 from sample PT22, Liščí Q.・D - Vistulella kozlowskii Kielan-Jaworowska, 1961, incomplete left MI No. PT26H.2 from sample PT26, Liščí Q. • E - Mochtyella sp. ex gr. fragilis Szaniawski, 1970, incomplete left MI No. PT20A.2 from sample PT20, Liščí Q. • F - Tetraprion sp. sensu Szaniawski, 1970 ?, MII? No. PT27.13 from sample PT23, Liščí Q. • G - Xanioprion aff. borealis, right MII No. PT27.14 from sample PT23, Liščí Q. • H, I - mochtyellids. H - right jaw No. PT9A.5 from sample PT9, Kosov Q. I - left MI No. PT1A.4 from sample PT1, Kosov Q. • J - Vistulella kozlowskii Kielan-Jaworowska, 1961 , left MI No. PT22H.3 from sample PT22, Liščí Q. • K, L - Pistoprion sp. A. K - right MI No. PT27.15 from sample PT23, Liščí Q. L - left and right MI, right MII from the same apparatus Nos. PT11C.2-4 from sample PT11, Kosov Q.•M-Lunoprionella symmetrica Eisenack, 1975, No. PT5A.5 from sample PT5, Kosov Q. - N-R - Pistoprion sp. A. N - left MI No. PT27.12 from sample PT26, Liščí Q. O - right MI No. PT11A.6 from sample PT11, Kosov Q. P - left MI No. PT11A.7 from sample PT11, Kosov Q. Q - right MI No. PT11B.2 from sample PT11, Kosov Q. R - left MI No. PT11A.8 from sample PT11, Kosov Q. - S - Xanioprion sp. A, left MII No. PT5C.7 from sample PT5, Kosov Q. • T - Xanioprion? sp. A, left MI No. PT26G.2 from sample PT26, Liščí Q. - U - Pistoprion sp. A, left MI No. PT9A.4 from sample PT9, Kosov Q. • V - Placognatha indet., No. PT22G.9 from sample PT22, Lišći Q. - W, X - Rakvereprion sp. A. W - flattened MI, No. PT5C.8 from sample PT5, Kosov Q. X - flattened MI No. PT5A.4 from sample PT5, Kosov Q. - Y - Placognatha indet., left jaw No. PT9B.4 from sample PT9, Kosov Q. • Z - Xanioprion sp., left MI No. PT7A.7 from sample PT7, Kosov Q. 
Petra Tonarová et al. • A jawed polychaete fauna across the late Ludlow Kozlowskii event interval (Prague Basin)

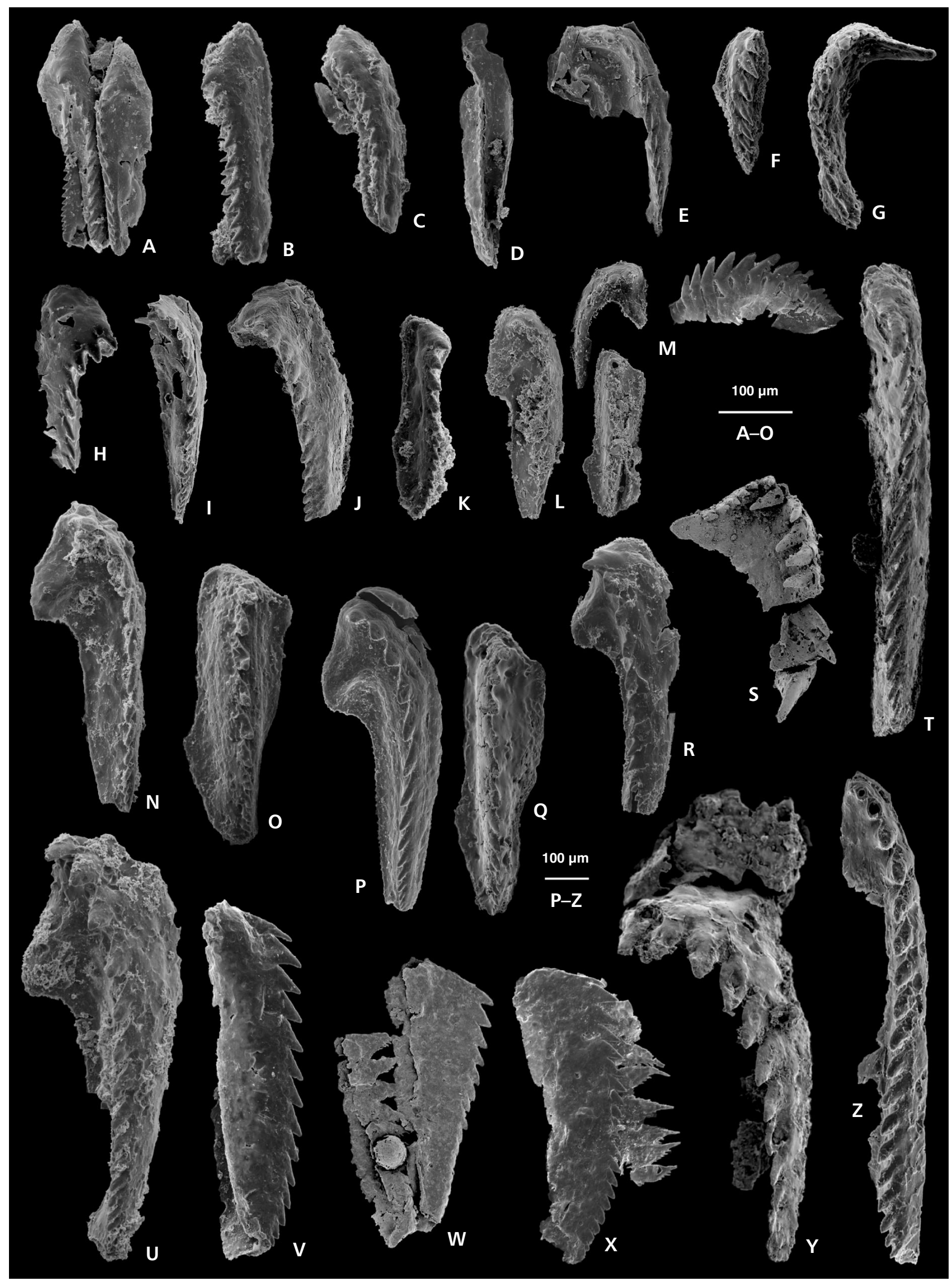


studied. Despite having an informal name here, this species is well known from several other Silurian regions around the world, including Gotland (Bergman 1979), Estonia (Hints et al. 2006, Rubel et al. 2007), Siberia (Männil \& Zaslavskaya 1985), and Arctic Canada (Hints et al. 2000). The latter authors have used the historical name Eunicites serrula Hinde, 1880 or Pistoprion serrula. However, inspection of Hinde's type material (by MEE and PT) suggests that this may be a misidentification ( $c f$. Eriksson et al. 2004). Therefore open nomenclature is used here with the aim to describe the species formally based on better preserved material than what is currently available from the Prague Basin. The stratigraphical range of Pistoprion sp. A seems to be rather extensive, spanning from at least the upper Llandovery to the Ludlow.

Pistoprion is regarded as being indicative of relatively shallow water facies, typical for nearshore environments and not occurring in the central part of palaeobasins (Hints 2000, Rubel et al. 2007). Its presence thus seems to support the interpretation of a relative sea-level fall in the studied stratigraphical interval (Lehnert et al. 2003, 2007).

\section{Genus Rakvereprion Mierzejewski, 1978}

Rakvereprion sp. A (Figs 3AB, 4W, X) has been recorded from the middle part of the sampled interval at Kosov Quarry. Rakvereprion Mierzejewski, 1978 possesses simple, symmetrical posterior maxillae and long basal and laeobasal plates that have secondarily denticulated ridges. Compared to the Upper Ordovician Rakvereprion balticus (Eisenack, 1975), the MI of the Kosov Quarry specimens are larger and their outline in lateral view is subrectangular rather than subtriangular. These differences may reflect evolutionary changes within the genus from the Late Ordovician to the Ludfordian. Previous Silurian occurrences of Rakvereprion are rare and limited to a few specimens recovered from the Llandovery/Wenlock boundary beds of Estonia (OH, unpublished data).
Several authors (Mierzejewski 1978; Hints 2000, 2001; Eriksson \& Frisk 2011) have noted that the Late Ordovician Rakvereprion is a stenotopic genus preferring deeper shelf settings. Thus the findings of Rakvereprion from the lower part of the Kosov Quarry section may reflect slightly different environmental settings than those in the upper part and of the Liščí Quarry section. This agrees with previous interpretations of an upwards shallowing environment (Horný 1955).

\section{Genus Vistulella Kielan-Jaworowska, 1961}

Vistulella kozlowskii Kielan-Jaworowska, 1961 (Figs 3W, $\mathrm{X}, 4 \mathrm{D}, \mathrm{J}$ ) is a rather common taxon in the collections studied. The left MI of Vistulella may be difficult to identify since similar elements are found also in other placognath taxa. Moreover, the right MI, especially if poorly preserved, are similar to those of Pistoprion. Therefore, some occurrences of Vistulella may have been overlooked (and placed within the Placognatha indet. category). Based on published records, the stratigraphical range of $V$. kozlowskii is one of the longest among Early Palaeozoic jawed polychaetes, extending from the Darriwilian (Hints \& Eriksson 2007a) to the Ludlow (the present collection). It cannot be excluded that this species name actually holds more than one species. However, at present a finer subdivision of individual species seems impossible. Geographically, Silurian Vistulella has been reported from Estonia (Hints et al. 2006), Gotland (MEE, unpublished data), Arctic Canada (Hints et al. 2000) and Severnaya Zemlya (Männil \& Zaslavskaya 1985). Adding the herein reported occurrence from Perunica, it can be seen that Vistulella was widely distributed in the Silurian.

\section{Family Xanioprionidae Kielan-Jaworowska, 1966}

Discussion. - Xanioprionids are common throughout both sections studied, below the Kozlowskii event. Unfortunately the specimens are quite often fragmented which

Figure 5. SEM micrographs of selected polychaetaspids, ramphoprionids and ?polychaeturids, all specimens are in dorsal view. Scale bar corresponds to $100 \mu \mathrm{m}$ except for Fig. R and AC where it corresponds to $200 \mu \mathrm{m}$. • A-G - Protarabellites cf. rectangularis Eriksson, 2001. A - left MI No. PT11A.3 from sample PT11, Kosov Quarry. B - right MI No. PT5C.2 from sample PT5, Kosov Q. C - right MI No. PT27.9 from sample PT9, Kosov Q. D - right MI No. PT5A.2 from sample PT5, Kosov Q. E - right MI No. PT7A.5 from sample PT7, Kosov Q. F - left MI No. PT9A.3 from sample PT9, Kosov Q. G - right MI No. PT25A.2 from sample PT25, Liščí Q. • H - Oenonites sp., left MI No. PT11A.5 from sample PT11, Kosov Q. • I-M - Oenonites cf. olavi Eriksson, 1997. I - left MI No. PT25A.3 from sample PT25, Liščí Q. J - left MI No. PT25A.4 from sample PT25, Liščí Q. K - left MI No. PT1A.3 from sample PT1, Kosov Q. L - right MI No. PT1A.2 from sample PT1, Kosov Q. M - right MI No. PT5C.6 from sample PT5, Kosov Q. • N-P - Oenonites cf. jennyensis Eriksson, 1997. N - right MI No. PT5C.5 from sample PT5, Kosov Q. O - right MI No. PT5C.4 from sample PT5, Kosov Q. P - left MI No. PT5C.3 from sample PT5, Kosov Q. • Q-V - Oenonites sp. Q - left MI No. PT13A.2 from sample PT13, Kosov Q. R - part of the apparatus No. PT9B.3 from sample PT9, Kosov Q. S - left MI No. PT9B.2 from sample PT9, Kosov Q. T - left MI No. PT26G.1 from sample PT26, Liščí Q. U - right MI No. PT7A.6 from sample PT7, Kosov Q. V - right MI No. PT5A.3 from sample PT5, Kosov Q.•W, X - Oenonites cf. gadomskae Kielan-Jaworowska, 1966. W - left MI No. PT26H.1 from sample PT26, Liščí Q. X - right MI No. PT23E.2 from sample PT23, Liščí Q. • Y-AB - Oenonites sp. Y - right MI No. PT22G.8 from sample PT22, Lišči Q. Z - left MI No. PT11C.1 from sample PT11, Kosov Q. AA - right MI No. PT11A.4 from sample PT11, Kosov Q. AB - right MI No. PT9A.2 from sample PT9, Kosov Q. • AC - Oenonites sp., left MI, No. PT23E.3 from sample PT23, Liščí Q. • AD - Pteropelta? sp., right MI No. PT9B.1 from sample PT9, Kosov Q. 


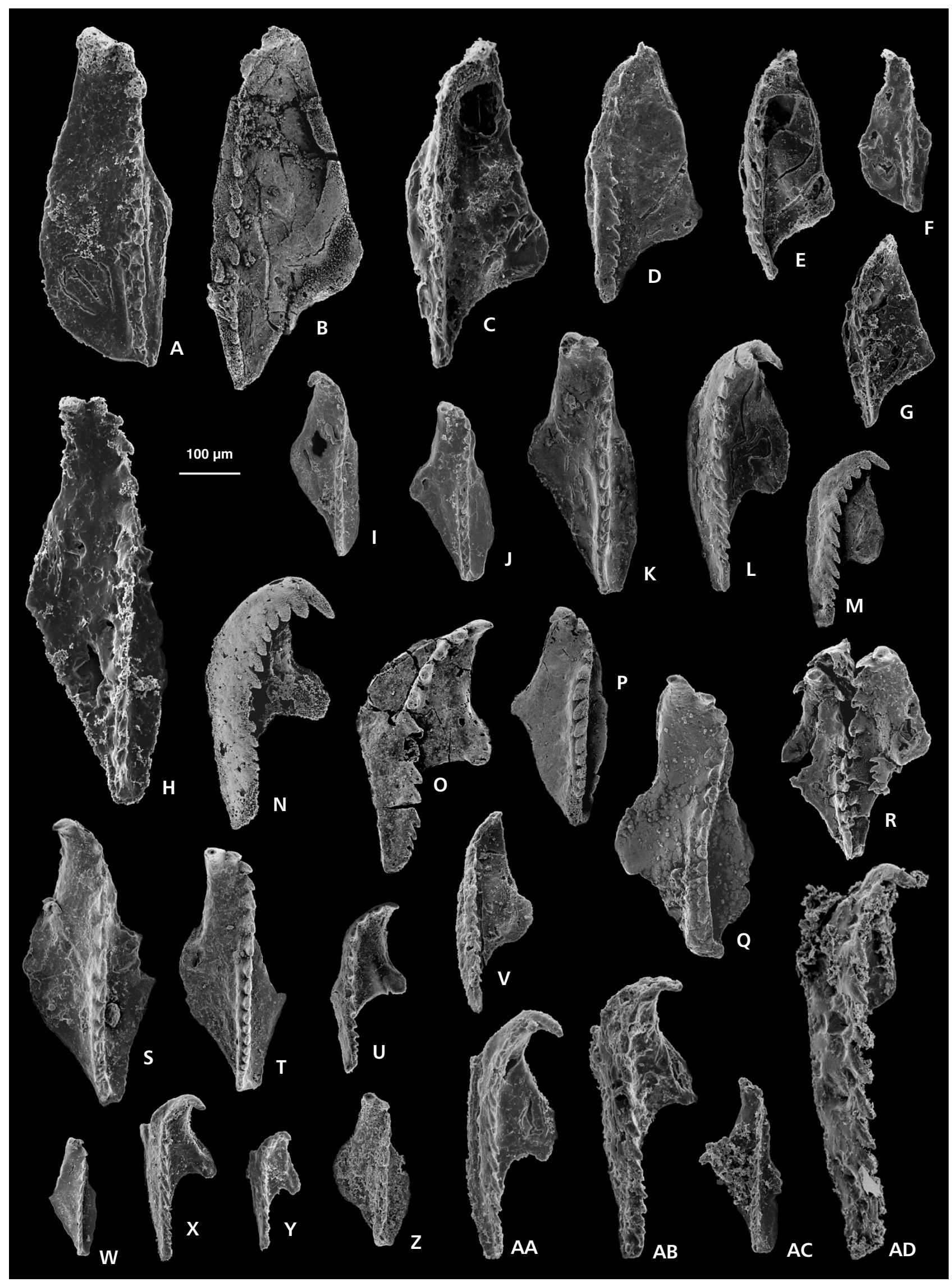


complicates proper determination and may distort their actual representation in the sections.

\section{Genus Xanioprion Kielan-Jaworowska, 1962}

Xanioprion aff. borealis Kielan-Jaworowska, 1962 (Fig. 4G). The second maxillae were found in both sections and are closely similar to those of $X$. borealis but additional elements are needed for unambiguous identification. Xanioprion borealis was originally described from Ordovician boulders from Poland (Kielan-Jaworowska 1962) and later the stratigraphical range was extended into the Wenlock (Eriksson et al. 2004). This taxon may be conspecific with Lumbriconereites falciformis Hinde, 1882, described from Gotland, Sweden.

Xanioprion sp. A. (Fig. 4S, T) is recorded throughout both sections. This species differs from $X$. aff. borealis in having wider outer face and concave posterior margins in MII and longer MI, developed as clearly discrete jaws. It resembles Xanioprion sp. B sensu Hints (2000) reported from the Darriwilian to Wenlock (Eriksson \& Hints 2009).

Family Tetraprionidae Kielan-Jaworowska, 1966

\section{Genus Tetraprion Kielan-Jaworowska, 1966}

?Tetraprion sp. sensu Szaniawski, 1970 (Fig. 4F). A single maxilla was found in sample PT23. Its identification is based on close similarity to forms discussed by Szaniawski (1970), Hints (2000), Hints \& Eriksson (2007a, figs 3G, H, P) and Rubel et al. (2007, fig. 6) from the Upper Ordovician to Wenlock of the Baltic region and North America. From the latter regions abundant isolated jaws and several fused apparatuses of the same genus have been recovered. The assignment to Tetraprion is, however, tentative; more likely it represents a new tetraprionid genus.
Family Symmetroprionidae Kielan-Jaworowska, 1966

\section{Genus Symmetroprion Kielan-Jaworowska, 1966}

Symmetroprion spatiosus (Hinde, 1882) (Fig. 6M). A single characteristic right MI was found in sample PT5 from Kosov Quarry. Symmetroprion is common in the Wenlock to late Ludlow reef-related environments on Gotland (Bergman 1995) and is known also to occur in shallow-water environments of Estonia (Rubel et al. 2007) and Arctic Canada (Hints 2000). Recently, Hints \& Eriksson (2007a) found the oldest members of the genus from the middle Upper Ordovician of the USA.

Family Polychaetaspidae Kielan-Jaworowska, 1966

\section{Genus Oenonites Hinde, 1879}

Discussion. - Oenonites is represented by at least five different species and accounts for more than one third of the scolecodonts in the collection. However, distinguishing individual species has in several samples been difficult (due to inadequate preservation) and thus they are grouped as Oenonites spp. in the distribution charts (Fig. 2). Three, more distinctive, species are listed below.

Oenonites aff. olavi Eriksson, 1997 (Fig. 5I-M) belongs to the latus group sensu Kielan-Jaworowska. The Prague specimens have more elongated posterior maxillae compared to those of $O$. olavi from Gotland, and resemble also those of Eriksson \& Hints (2009, fig. 4M) and Hints (1998, fig. 10R).

Oenonites aff.jennyensis Eriksson, 1997 (Fig. 5N-P) has been found in both quarries. This species has a distinct posterior extension of the ridge in the left MI. Unlike in O. jennyensis from Gotland, Sweden, the extension is proximally directed and not "forked" in the Prague specimens.

Figure 6. SEM micrographs of selected paulinitids, kalloprionids and symmetroprionids. All specimens are in dorsal view except $\mathrm{H}$, in ventral view. Scale bar refers to all figures, except for A to D that have separate scale bar. • A, C, E-K - Kettnerites kosoviensis Žebera, 1935. A - left MI No. PT15A.1 from sample PT15, Kosov Quarry. C - right MII No. PT9A.1 from sample PT9, Kosov Q. E - right MI No. PT22G.10 from sample PT22, Liščí Q. F - right MI No. PT22G.7 from sample PT22, Liščí Q. G - right MI No. PT20A.1 from sample PT20, Liščí Q. H - right MI No. PT10A.1 from sample PT10, Kosov Q. I - left MI No. PT11A.2 from sample PT11, Kosov Q. J - left MI No. PT11B.1 from sample PT11, Kosov Q. K - right MII No. PT22H.2 from sample PT22, Liščí Q. • B, D, Y-AC - Different morphotypes of Kettnerites; deformation or poor preservation hampered species determination. B - right MII No. PT13A.1 from sample PT13, Kosov Q. D - right MI No. PT7A.4 from sample PT7, Kosov Q. Y - right MII No. PT1A.1 from sample PT1, Kosov Q. Z - right MII No. PT22G.1 from sample PT22, Liščí Q. AA - right MII No. PT5A.1 from sample PT5, Kosov Q. AB - right MI No. PT7A.2 from sample PT7, Kosov Q. AC - right MII No. PT7A.1 from sample PT7, Kosov Q. • L - Leptoprion? sp., right MI No. PT5C.1from sample PT5, Kosov Q. • M - Symmetroprion spatiosus (Hinde, 1882), right MI No. PT5B.1 from sample PT5, Kosov Q. • N-X - Kettnerites cf. sisyphi Bergman, 1987. N - left MI No. PT7A.3 from sample PT7, Kosov Q. O - left MI No. PT25A.1 from sample PT25, Liščí Q. P - left MI No. PT22G.6 from sample PT22, Liščí Q. Q - right MI No. PT5A.6 from sample PT5, Kosov Q. R - right MI No. PT27.8 from sample PT24, Liščí Q. S - right MI No. PT22G.11 from sample PT22, Liščí Q. T - left MII No. PT11A.1 from sample PT11, Kosov Q. U - right MII No. PT22G.5 from sample PT22, Liščí Q. V - right MII No. PT22G.4 from sample PT22, Liščí Q. W - right MII No. PT22G.3 from sample PT22 Liščí Q. X - left MII No. PT22G.2 from sample PT22, Liščí Q. 
Petra Tonarová et al. • A jawed polychaete fauna across the late Ludlow Kozlowskii event interval (Prague Basin)

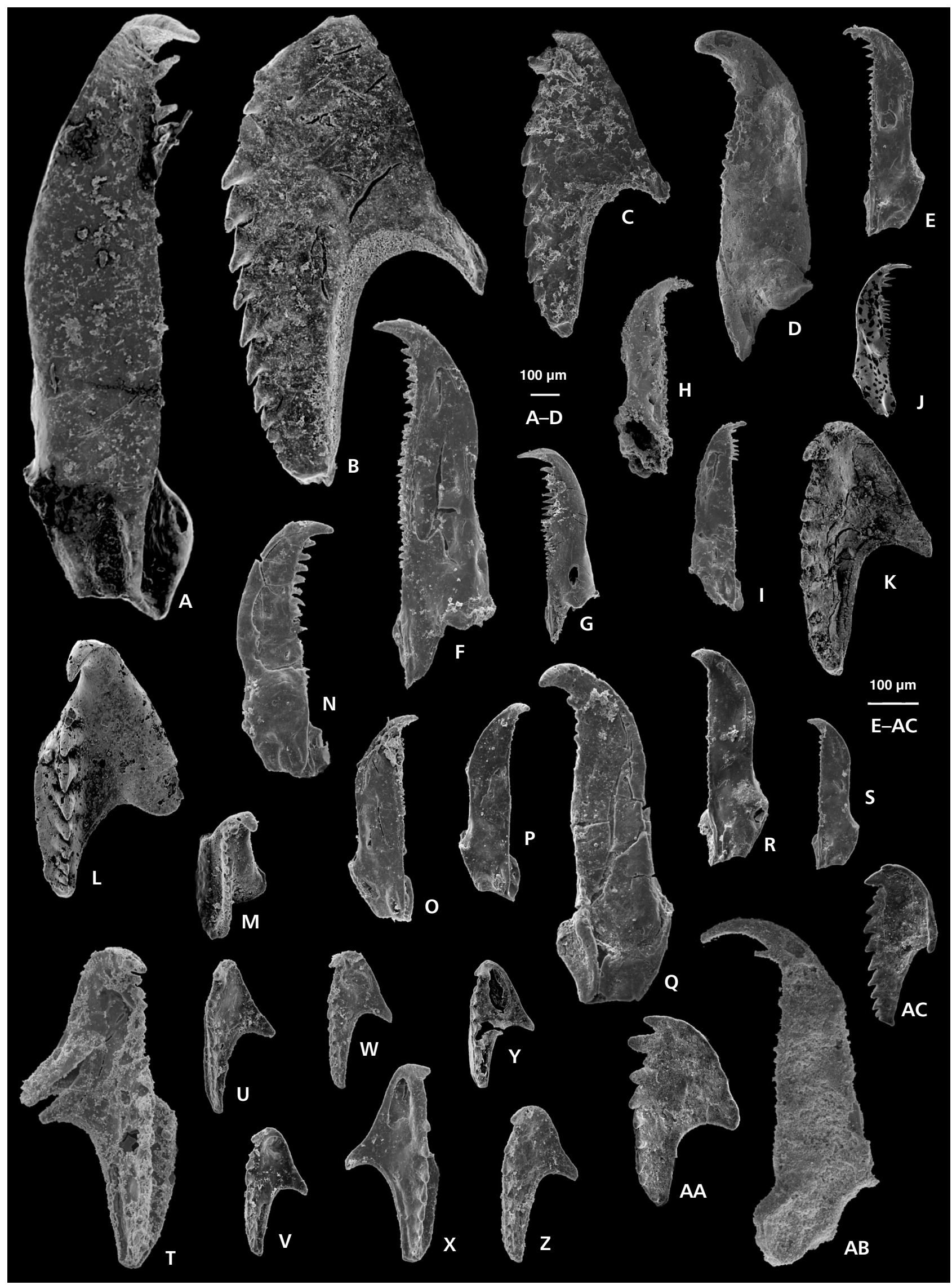


Oenonites cf. gadomskae Kielan-Jaworowska, 1966 (Fig. 5W, X) is virtually indistinguishable from the Ordovician material illustrated by Kielan-Jaworowska (1966), Hints (2000) and Hints \& Eriksson (2007a).

Family Polychaeturidae Kielan-Jaworowska, 1966

\section{Genus Pteropelta Eisenack, 1939}

Pteropelta? sp. (Fig. 5AD). The polychaeturid genus Pteropelta is identified in the present collection on the basis of one right MI found in sample PT9 from the Kosov Quarry. The elongated jaw has a very long shank, narrow ramus and missing bight. The dentary has 11 fairly large denticles, of which the three following the fang are smaller than the subsequent ones. In overall shape the specimen resembles the Late Ordovician morphotype of Pteropelta gladiata (Eisenack, 1939), illustrated by Hints \& Eriksson (2010, figs 1P, Q), but it is considerably narrower and has a differentiated dentary. It may be argued that the morphological trend observed in the long-ranging P. gladiata through the Ordovician by Hints \& Eriksson (2010) continued into the Silurian. Previously, polychaeturids have only been recorded from the Ordovician and lowermost Silurian and hence the present finding would extend their range to the upper Silurian. However, since the left MI are most diagnostic for polychaeturids, the present identification must be considered as only tentative and additional material is needed for an unambiguous assessment.

Family Ramphoprionidae Kielan-Jaworowska, 1966

\section{Genus Protarabellites Stauffer, 1933}

Protarabellites cf. rectangularis Eriksson, 2001 (Fig. 5A-G) is present in both quarries and approximately 20 first maxillae were recovered. The Prague specimens are, similar to those reported from Skåne, southernmost Sweden (Eriksson 2002), intermediate between $P$. rectangularis Eriksson, 2001 and P. triangularis Eriksson, 2001. As noted also by Eriksson (2001), these species can be difficult to distinguish from each other, particularly if the specimens are deformed or otherwise poorly preserved.

\section{Genus Ramphoprion Kielan-Jaworowska, 1962}

Ramphoprion cf. gotlandensis Eriksson, 2001. One poorly preserved MI of this species was found in sample PT2 (specimen PT2A.1), the Kosov Quarry.
Family Kalloprionidae Kielan-Jaworowska, 1966

\section{Genus Kalloprion Kielan-Jaworowska, 1962}

Kalloprion sp. is very rare in the collection studied; poorly preserved first maxillae were recorded in two samples (PT6, PT7) only.

\section{Genus Leptoprion Kielan-Jaworowska, 1966}

Leptoprion? sp. (Figs 3AA, 6L). Only one maxilla has been found, in sample PT5; another fragmentary specimen was found in sample PT10, both from the Kosov Quarry. Morphologically this species is intermediate between Leptoprion and Atraktoprion Kielan-Jaworowska, 1962, having a longer fang and larger denticles than those in typical Leptoprion. Closely similar, probably conspecific, specimens have been described from Arctic Canada (Hints et al. 2000) and are known from Gotland and Estonia (MEE and $\mathrm{OH}$, unpublished data). Arabellites spicatus described by Hinde (1882, p. 18, pl. 2, fig. 47, sample No A2216) from Gotland also seems to be closely related.

Family Paulinitidae Lange, 1947

Discussion. - Paulinitids occur abundantly but are represented only by Kettnerites Žebera, 1935. Specimens of Kettnerites are recorded in all but one of the scolecodont-yielding samples. Based on the morphology of the second maxillae, which according to Bergman (1989) are the most diagnostic elements in paulinitids, at least two different species (listed below) can be distinguished in the studied material. Representatives of this genus also dominate on the bedding plane surfaces of the Kopanina Formation shale intercalations as confirmed by previous studies and the new sampling. Their dominance could be artificially inflated because of their quite easy identification even on fragments and the relatively resistant nature of, particularly, the first and second maxillae. In the Baltic region and the Welsh Borderland of the British Isles contemporaneous strata commonly yield also Lanceolatites Bergman, 1987 which is missing in the Prague Basin. The distribution of Silurian paulinitids is discussed in detail by Bergman $(1987,1989)$ who described more than 20 species from Gotland.

\section{Genus Kettnerites Žebera, 1935}

Kettnerites kosoviensis Žebera, 1935 sensu Šnajdr 1951 (Fig. 6A, C, E-K) is distinguished especially by its double-cusped right MII. This species has been recorded with certainty only from the Prague Basin. Taugourdeau 
(1967) described K. kosoviensis from France and Taugourdeau (1972) and Taugourdeau \& Iliescu (1983) recorded $K$. cf. kosoviensis from the Sahara and Romania, respectively. However, that material needs restudy.

Kettnerites cf. sisyphi Bergman, 1987 (Fig. 6N-X). The right MII of this species has one small precuspidal denticle and particularly resembles K. sisyphi Bergman, 1987 from Gotland. Similar specimens are known also for example from the Wenlock of the Canadian Arctic (Hints et al. 2000) and Estonia (Hints et al. 2006).

Kettnerites spp. (Fig. 6B, D, Y-AC). In addition to the above mentioned Kettnerites species, other species are present within the collection. However, due to imperfect preservation and insufficient material for apparatus reconstructions, these cannot presently be identified to species level.

Family Tretoprionidae Hints, 1999

\section{Genus Tretoprion Hints, 1999}

Tretoprion astae Hints, 1999 (Fig. 3AC). A single right MI of this enigmatic species was recorded in sample PT5 from the Kosov Quarry. It has a slender shank and ramus and transversally extended denticles in the anterior part of the dentary. This species was first described from the Upper Ordovician of Estonia (Hints 1999), but rare specimens have subsequently also been found from the upper Llandovery and lower Wenlock of the same area (Hints et al. 2006) and from the Upper Ordovician of subsurface Gotland, Sweden (Eriksson \& Hints 2009). The Kosov Quarry specimen extends the stratigraphical range of the genus into the Ludlow, and shows also its wide geographical distribution.

Family uncertain

\section{Genus Lunoprionella Eisenack, 1975}

Lunoprionella symmetrica Eisenack, 1975 (Figs 3Z, AD, AE, 4M) is represented by approximately 20 specimens from both quarries. The family affinity and apparatus arrangement of this species are unknown. The stratigraphical range of the genus is from the Middle Ordovician to the upper Silurian. For further discussion of Lunoprionella, see Hints (1998).

\section{Conclusions}

1. The collection of scolecodonts from the Prague Basin represents the most diverse Silurian jawed polychaete fauna hitherto recorded from the peri-Gondwanan region.

2. The Ludfordian polychaete faunas described from the Kosov and Lišćí quarries include at least 16 genera, of which Kettnerites, Oenonites and Pistoprion are most common.

3. The faunal composition corresponds well with that of coeval faunas, particularly from Baltica and, to some extent, Avalonia, Laurentia and Siberia. The Prague Basin material extends the palaeolatitudinal and palaeobiogeographical distribution of some genera (Protarabellites, Symmetroprion, Kalloprion and Tretoprion). Collectively, this suggests a geographically widespread nature of the Silurian polychaete faunas.

4. The abundance and relatively good preservation of the scolecodonts recovered through acid digestion of rocks, clearly show the limitations of the historical bedding plane collections and suggest good potential for future studies.

5. The Kozlowskii event reorganised the polychaete fauna in the Prague Basin, although additional highresolution sampling is needed in order to accurately evaluate the precise impact of the event.

\section{Acknowledgements}

David Loydell, Hubert Szaniawski and Štěpán Manda critically reviewed the manuscript and made valuable suggestions for its improvement. Oldřich Fatka is thanked for his invaluable advice to PT. The research was supported by the Grant Agency of the Charles University through project No. 46209, Czech Science Foundation through project No. 205/09/1521, by the Czech Ministry of Education through project SVV 261203 and by the Czech Geological Survey through research project No. 32300. This research received support also from the SYNTHESIS Project http://www.synthesis.info that is financed by European Community Research Infrastructure Action under the FP7. MEE is funded by the Swedish Research Council. The paper is a contribution to IGCP 591.

\section{References}

Armstrong, H.A. \& Owen, A.W. 2002. Euconodont paleobiogeography and the closure of the Iapetus Ocean. Geology 30, 1091-1094.

DOI 10.1130/0091-7613(2002)030<1091:EPATCO >2.0.CO;2

Barrick, J.E., Kleffner, M.A., Gibson, M.A., Peavey, F.N. \& Karlsson, H.R. 2010. The mid-Ludfordian Lau Event and Carbon Isotope Excursion (Ludlow, Silurian) in southern Laurentia - preliminary results. Bollettino della Società Paleontologica Italiana 49(1), 13-33.

Bergman, C. 1979. Polychaete jaws, 92-102. In JaAnusson, V., LAufeld, S. \& SKoglund, R. (eds) Lower Wenlock faunal and floral dynamics - Vattenfallet section, Gotland. Sveriges Geologiska Undersökning C 762. 
BERGMAN, C.F. 1987. Silurian paulinitid jawed polychaetes from Gotland. 145 pp. Ph.D. dissertation, Lund University, Lund, Sweden.

Bergman, C.F. 1989. Silurian paulinitid polychaetes from Gotland. Fossils and Strata 25, 1-128.

Bergman, C.F. 1995. Symmetroprion spatiosus (Hinde), a jawed polychaete showing preference for reef environments in the Silurian of Gotland. GFF 117, 143-150. DOI 10.1080/11035899509546210

BouČEK, B. 1941. O novém odkryvu siluru u Loděnic. Zprávy Geologického ústavu pro Čechy a Moravu 17(4), 165-172.

CALNER, M. 2005. A Late Silurian extinction event and anachronistic period. Geology 33, 305-308. DOI 10.1130/G21185.1

CALner, M. 2008. Silurian global events at the tipping point of climate change, 21-57. In ElEwA, A.M.T. (ed.) Mass Extinction. Springer-Verlag, Berlin, Heidelberg.

ČÁP, P. 2002. The microfacies of limestone of the Ludlow-Přídolí boundary at selected localities in the Barrandian area. Zprávy o geologických výzkumech v roce 2001, 15-17.

ČÁP, P., VACEK, F. \& Vorel, T. 2003. Microfacies analysis of Silurian and Devonian type sections (Barrandian, Czech Republic). Special Papers, Czech Geological Survey 15, 1-40.

Chlupáč, I., HavlíčeK, V., KŘižž, J., Kukal, Z. \& ŠTorch, P. 1998. Palaeozoic of the Barrandian (Cambrian to Devonian). 183 pp. Czech Geological Survey, Prague.

Cocks, L.R.M. \& ToRsvik, T.H. 2002. Earth geography from 500 to 400 million years ago: a faunal and palaeomagnetic review. Journal of the Geological Society, London 159, 631-644. DOI 10.1144/0016-764901-118

Conway Morris, S. 1979. Middle Cambrian polychaetes from the Burgess Shale of British Columbia. Philosophical Transactions of the Royal Society of London, Series B, Biological Sciences 285(1007), 227-274. DOI 10.1098/rstb.1979.0006

Conway Morris, S. 1985. Cambrian Lagerstätten: their distribution and significance. Philosophical Transactions of the Royal Society of London, Series B, Biological Sciences 311(1148), 49-65. DOI 10.1098/rstb.1985.0138

Croneis, C. \& Scott, H.W. 1933. Scolecodonts. Bulletin of the Geological Society of America 44, 207.

EISENACK, A. 1939. Einige neue Annelidenreste aus dem Silur und dem Jura des Baltikums. Zeitschrift für Geschiebeforschung und Flachlandsgeologie 15(3), 153-176.

Eisenack, A. 1975. Beiträge zur Anneliden - Forschung, I. Neues Jahrbuch für Geologie und Paläontologie, Abhandlungen 150(2), 227-252.

ElLER, E.R. 1963. Scolecodonts from the Dundee, Devonian of Michigan. Annals of Carnegie Museum 36, 173-180.

ERIKSSON, M. 1997. Lower Silurian polychaetaspid polychaetes from Gotland, Sweden. GFF 119, 213-230. DOI 10.1080/11035899709546480

ERIKSSON, M. 1998. Dubichaetaspis bergmani gen. et sp. n., a facies controlled polychaete from the Silurian of Gotland, Sweden. GFF 120, 21-25. DOI 10.1080/11035899801201021

ERIKSSON, M. 2001. Silurian ramphoprionid polychaetes from Gotland, Sweden. Journal of Paleontology 75, 993-1015. DOI 10.1666/0022-3360(2001)075<0993:SRPFGS >2.0.CO;2

ERIKSSON, M. 2002. The palaeobiogeography of Silurian ramphoprionid polychaete annelids. Palaeontology 45, 985-996. DOI 10.1111/1475-4983.00272
ERIKSSON, M. 2006. The Silurian Ireviken Event and vagile benthic faunal turnovers (Polychatea; Eunicida) on Gotland, Sweden. GFF 128(2), 91-95. DOI 10.1080/11035890601282091

Eriksson, M.E., Bergman, C.F. \& Jeppsson, L. 2004. Silurian scolecodonts. Review of Palaeobotany and Palynology 131, 269-300. DOI 10.1016/j.revpalbo.2004.04.001

ERIKSSON, M. \& Frisk, Å.M. 2011. Polychaete palaeoecology in an early Late Ordovician marine astrobleme of Sweden. Geological Magazine 148(2), 269-287.

DOI $10.1017 /$ S0016756810000579

ERIKSSON, M.E. \& HiNTS, O. 2009. Vagrant benthos (Annelida, Polychaeta) associated with Upper Ordovician carbonate mud-mounds of subsurface Gotland, Sweden. Geological Magazine 146(3), 451-462.

DOI 10.1017/S0016756809005962

Eriksson, M.E., Hints, O., PaXton, H. \& Tonarová, P. in press. Ordovician and Silurian polychaete diversity and biogeography. Geological Society of London, Bulletin.

Eriksson, M.E., NiLsson, E.K. \& Jeppsson, L. 2009. Vertebrate extinctions and reorganizations during the Late Silurian Lau Event. Geology 37, 739-42. DOI 10.1130/G25709A.1

FatKa, O. \& Mergl, M. 2009. The "microcontinent" Perunica: status and story 15 years after conception. Geological Society of London, Special Publications 325, 65-101. DOI 10.1144/SP325.4

Ferretti, A. \& KŘižž, J. 1995. Cephalopod limestone biofacies in the Silurian of the Prague Basin, Bohemia. Palaios 10(3), 240-253. DOI 10.2307/3515255

GruBE, A.E. 1855. Beschreibungen neuer oder wenig bekannter Anneliden. Archiv für Naturgeschichte, Berlin 21(1), 81-128.

HAvLíčEK, V. 1981. Development of a linear sedimentary depression exemplified by the Prague Basin (Ordovician-Middle Devonian; Barrandian area-central Bohemia). Sborník geologických věd, Geologie 35, 7-48.

HavlíčEK, V. 1982. Ordovician in Bohemia; development of the Prague Basin and its benthic communities. Sborník geologických věd, Geologie 37, 103-136.

HaVlíčEK, V. 1999. Perunica microplate: relation to Ukranian Shield, mid-Bohemian rift, and hypothetic large-scale overthrust in Central Bohemia. Věstník Českého geologického ústavu 74(1), 75-81.

HavlíčEK, V. \& ŠTORCh, P. 1990. Silurian brachiopods and benthic communities in the Prague Basin (Czechoslovakia). Rozpravy Ústredního ústavu geologického 48, 1-275.

HavlíčeK, V., VaněK, J. \& FatKa, O. 1994. Perunica microcontinent in the Ordovician (its position within the Mediterranean Province, series division, benthic and pelagic associations). Sborník geologických věd, Geologie 46, 23-56.

HindE, G.J. 1879. On annelid jaws from the Cambro-Silurian, Silurian and Devonian formations in Canada and from the Lower Carboniferous in Scotland. Quarterly Journal of the Geological Society of London 35(139), 370-389.

DOI 10.1144/GSL.JGS.1879.035.01-04.24

HindE, G.J. 1880. On annelid jaws from the Wenlock and Ludlow formations of the West of England. Quarterly Journal of the Geological Society of London 36(143), 368-378.

DOI 10.1144/GSL.JGS.1880.036.01-04.30

HiNDE, G.J. 1882. On annelid remains from the Silurian strata of 
the Isle of Gotland. Bihang till Kunliga Vetenskapsakademiens Handlingar 7(5), 1-28.

HinTs, O. 1998. Late Viruan (Caradoc) polychaete jaws from North Estonia and the St. Petersburg region. Acta Palaeontologica Polonica 43, 471-516.

HinTs, O. 1999. Two new polychaete families from the Upper Ordovician of Estonia. Palaeontology 42(5), 897-906. DOI 10.1111/1475-4983.00101

HinTs, O. 2000. Ordovician eunicid polychaetes of Estonia and surrounding areas: a review of their distribution and diversification. Review of Palaeobotany and Palynology 113, 41-55. DOI 10.1016/S0034-6667(00)00051-8

Hints, O. 2001. Distribution of scolecodonts, 12-14. In PõLDVERE, A. (ed.) Estonian Geological Sections. Bulletin 3. Valga (10) drill core. Geological Survey of Estonia, Tallinn.

Hints, O., Bergman, C.F. \& Märss, T. 2000. Silurian jawed polychaetes from Cornwallis and Baillie-Hamilton islands, Canadian Arctic, 35-38. In Antoshrina, A., Malysheva, E. \& Wilson, M.V.H. (eds) Pan-Arctic Palaeozoic tectonics, evolution of basins and faunas.

HinTs, O. \& ERIKSSON, M.E. 2007a. Diversification and biogeography of scolecodont-bearing polychaetes in the Ordovician. Palaeogeography, Palaeoclimatology, Palaeoecology 245(1-2), 95-114. DOI 10.1016/j.palaeo.2006.02.029

Hints, O. \& ERiksson, M.E. 2007b. Biogeography of Ordovician and Silurian jaw-bearing polychaetes. Acta Palaeontologica Sinica, Supplement 46, 181-187.

Hints, O. \& ERIKSSON, M.E. 2010. Ordovician polychaeturid polychaetes: Taxonomy, distribution and palaeoecology. Acta Palaeontologica Polonica 55(2), 309-320.

DOI 10.4202/app.2009.0086

Hints, O., Killing, M., Männik, P. \& Nestor, V. 2006. Frequency patterns of chitinozoans, scolecodonts, and conodonts in the upper Llandovery and lower Wenlock of the Paatsalu core, western Estonia. Proceedings of the Estonian Academy of Sciences 55(2), 128-155.

HoRNÝ, R. 1955. Studie o vrstvách budňanských v západní části Barrandienu. Věstník Ústředního ústavu geologického, Geologie 21(2), 315-447.

Horný, R. 1962. Das mittelböhmische Silur. Geologie 11(8), 873-916.

Hutchings, P.A. \& Fauchald, K. 2000. Definition and general description, 1-3. In BeEsley, P.L., Ross, G.J.B. \& Glasby, C.J. (eds) Polychaetes \& allies: the southern synthesis. Fauna of Australia. Vol. 4A - Polychaeta, Myzostomida, Pogonophora, Echiura, Sipuncula. CSIRO Publishing, Melbourne.

JANSONIUS, J. \& CRAIG, J.H. 1972. Some scolecodonts in organic association from Devonian strata of Western Canada. American Association of Stratigraphic Palynologists 5, 15-26. DOI $10.2307 / 3687288$

JEPPSSON, L. 1993. Silurian events: the theory and the conodonts. Proceedings of the Estonian Academy of Sciences, Geology 42, 23-27.

JePPSSOn, L. \& AldRIDGE, R.J. 2000. Ludlow (late Silurian) oceanic episodes and events. Journal of the Geological Society, London 157, 1137-1148. DOI 10.1144/jgs.157.6.1137

Kielan-JaworowsKA, Z. 1961. On two Ordovician polychaete jaw apparatuses. Acta Palaeontologica Polonica 6(3), 237-259.
Kielan-JaworowsKa, Z. 1962. New Ordovician genera of polychaete jaw apparatuses. Acta Palaeontologica Polonica 7(3-4), 291-332.

Kielan-JAWOROWSKA, Z. 1966. Polychaete jaw apparatuses from the Ordovician and Silurian of Poland and a comparison with modern forms. Palaeontologia Polonica 16, 1-152.

KŘiž, J. 1986. Silurian, 26-33. In HAVLíčEK, V. (ed.) Explanation of the geological map ČSSR $1: 25$ 000, 12-414 Černošice. Ústřední ústav geologický, Prague.

KŘiž, J. 1991. The Silurian of the Prague Basin (Bohemia) - tectonic, eustatic and volcanic controls on facies and faunal development, 179-203. In BAssetT, M.G., LANE, P.D. \& EDwards, D. (eds) The Murchison Symposium: Proceedings of an International Conference on The Silurian System. Special Papers in Palaeontology 44.

Ǩ̌iž, J. 1992. Silurian field excursions: Prague Basin (Barrandian) Bohemia. 111 pp. National Museum of Wales, Geological Series No. 13, Cardiff.

KŘiž, J. 1999. Silurian Bivalvia evolution, palaeocology, palaeogeography, importance for biostratigraphy and correlation. Abhandlungen der Geologischen Bundensanstalt 54, 377-384.

KŘiž, J. 2008. A new bivalve community from the lower Ludlow of the Prague Basin (Perunica, Bohemia). Bulletin of Geosciences 83(3), 237-280.

KukAL, Z. 1955a. Petrografický výzkum vrstev kopaninských v západních částech barrandienského siluru. Acta Universitatis Carolinae 1(1), 71-110.

KuKAL, Z. 1955b. Výzkum silurských dolomitických vápenců u Mořiny. Sborník Ústředního ústavu geologického 21(2), 225-250.

LANGE, F.W. 1947. Annelidos poliquetos dos folhelhos devonianos do Paraná. Arquivos do Museu Paranaese 6(5), 161-230.

Lehnert, O., FrÝda, J., Buggisch, W. \& MAnda, Š. 2003. A first report of the Ludlow Lau event from the Prague Basin (Barrandian, Czech Republic). Proceedings of the Field Meeting of the Subcommission on Silurian Stratigraphy, Serie Correlacion Geologica 18, 139-144.

Lehnert, O., FrÝda, J., Buggisch, W., Munnecke, A., NütZel, A., KŘiž, J. \& MANDA, Š. 2007. $\delta^{13}$ C records across the late Silurian Lau event: New data from middle palaeo-latitudes of northern peri-Gondwana (Prague Basin, Czech Republic). Palaeogeography, Palaeoclimatology, Palaeoecology 245, 227-244. DOI 10.1016/j.palaeo.2006.02.022

MANDA, Š. 2007. New Silurian nautiloids Phragmoceras Broderip, 1839, and Tubiferoceras Hedström, 1917, from the Prague Basin (Bohemia). Bulletin of Geosciences 82(2), 119-131. DOI 10.3140/bull.geosci.2007.02.119

MANDA, Š. 2008. Palaeoecology and palaeogeographic relations of the Silurian phragmoceratids (Nautiloidea, Cephalopoda) of the Prague Basin (Bohemia). Bulletin of Geosciences 83(1), 39-62. DOI 10.3140/bull.geosci.2008.01.039

MANDA, Š. \& KŘiž, J. 2006. Environmental and biotic changes in subtropical isolated carbonate platforms during the Late Silurian Kozlowskii Event, Prague Basin. GFF 128(2), 161-168. DOI 10.1080/11035890601282161

Manda, S̆., S̆ToRCh, P., Slavík, L., FrÝda, J., KŘ́̌̌̌, J. \& TASÁRYOVÁ, Z. 2012. The graptolite, conodont and sedimentary record through the late Ludlow Kozlowskii Event (Silurian) in 
the shale-dominated succession of Bohemia. Geological Magazine 149(3), 507-531. DOI 10.1017/S0016756811000847

Männil, R.M. \& Zaslavskaya, N.M. 1985. Silurian polychaetes from the northern Siberia. 98-119, 127-130. In GudinA, V.I. \& Kanigin, A.V. (eds) Phanerozoic microfauna from Siberia with surroundings. Trudy Instituta Geologii $i$ Geofiziki 615.

Melchin, J.M., Koren', T.N. \& ŠToRCh, P. 1998. Global diversity and survivorship patterns of Silurian graptoloids. New York State Museum Bulletin 491, 165-81.

Michel, C. \& DeVillez, E.J. 1978. Digestion, 509-554. In Mill, P.J. (ed.) Physiology of annelids. Academic Press, London.

MierzeJewski, P. 1978. New placognath Eunicida (Polychaeta) from the Ordovician and Silurian of Poland. Acta Geologica Polonica 28(2), 273-281.

Mikulás̆, R., ČÁP, P. \& HoRnÝ, R.J. 2003. Cherts of the Přídolí Formation and accompanying trace fossils (Pridoli, Silurian), Barrandian area, Czech Republic. Bulletin of Geosciences 78(4), 447-457.

Munnecke, A., SAmtleben, C. \& Bickert, T. 2003. The Ireviken Event in the lower Silurian of Gotland, Sweden - relation to similar Palaeozoic and Proterozoic events. Palaeogeography, Palaeoclimatology, Palaeoecology 195, 99-124. DOI 10.1016/S0031-0182(03)00304-3

Paxton, H. 2000. Eunicida, 89-104. In Beesley, P.L., Ross, G.J.B. \& Glasby, C.J. (eds) Polychaetes \& allies: the southern synthesis. Fauna of Australia. Vol 4A - Polychaeta, Myzostomida, Pogonophora, Echiura, Sipuncula. CSIRO Publishing, Melbourne.

Perner, J. 1894. O conodontu z českého siluru. Rozpravy České akademie císaře Františka Josefa pro vědy, slovesnost a umění, třída II (matematicko-př́rodnická) 3(2), 1-4.

Rubel, M., Hints, O., MÄnnik, P., Meidla, T., Nestor, V., SARV, L. \& SiBul, I. 2007. Lower Silurian biostratigraphy of the Viirelaid core, western Estonia. Estonian Journal of Earth Sciences 56(4), 193-204. DOI 10.3176/earth.2007.01

Slavík, L., Kř́iž, J. \& Carls, P. 2010. Reflection of the midLudfordian Lau Event in conodont faunas of Bohemia. Bulletin of Geosciences 85(3), 395-414.

ŠNAJDR, M. 1951. O errantních Polychaetech z českého spodního paleozoika. Sborník Ústředního ústavu geologického 18, 241-292.

Stauffer, C.R. 1933. Middle Ordovician Polychaeta from Minnesota. Bulletin of the Geological Society of America 44, 1173-1218.

ŠToRCH, P. 1994. Graptolite biostratigraphy of the lower Silurian (Llandovery and Wenlock) of Bohemia. Geological Journal 29, 137-165. DOI 10.1002/gj.3350290204

ŠToRCH, P. 1995. Upper Silurian (upper Ludlow) graptolites of the $N$. inexpectatus and N. kozlowskii biozones from Kosov Quarry near Beroun (Barrandian area, Bohemia). Bulletin of the Czech Geological Survey 70, 65-89.

Štorch, P., FAtKa, O. \& Kraft, P. 2006. Lower Palaeozoic of the Barrandian area, 9-10. In FATKA, O. \& KvAČEK, J. (eds) Excursions guide book, $7^{\text {th }}$ European palaeobotany-palynology conference. Prague.

Strickanne, L., Munnecke, A. \& Pross, J. 2006. Assessing mechanisms of environmental change: palynological signals across the late Ludlow (Silurian) positive isotope excursion $\left(\delta^{13} \mathrm{C}, \delta^{18} \mathrm{O}\right)$ on Gotland, Sweden. Palaeogeography, Palaeoclimatology, Palaeoecology 230, 1-31.

StRidSBERG, S. 1985. Silurian oncocerid cephalopods from Gotland. Fossils and Strata 18, 1-65.

Stridsberg, S. \& Turek, V. 1997. A revision of the Silurian nautiloid genus Ophioceras Barrande. GFF 119, 21-36. DOI 10.1080/11035899709546450

Svoboda, J. \& Prantl, F. 1954. O stratigrafii a tektonice staršího paleozoika v širším okolí Karlštejna. Sborník Ústředního ústavu geologického, Oddíl geologický 21(1), 519-596.

SzANIAWSKI, H. 1970. Jaw apparatuses of the Ordovician and Silurian polychaetes from the Mielnik borehole. Acta Palaeontologica Polonica 15(4), 445-472.

Szaniawski, H. 1996. Scolecodonts, 337-354. In Jansonius, J. \& McGregor, D.C. (eds) Palynology: principles and applications. American Association of Stratigraphic Palynologists Foundation 1.

Tait, J.A., Bachtadse, V., Franke, W. \& Soffel, H.C. 1997. Geodynamic evolution of the European Variscan fold belt: palaeomagnetic and geological constraints. Geologische Rundschau 86, 585-598. DOI 10.1007/s005310050165

Taugourdeau, P. 1967. Scolécodontes du Siluro-Devonien du Cotentin. Bulletin de la Société géologique de France 9(3), 467-474.

TAugourdeau, P. 1972. Debris cuticulaires d'Annelides associes aux Scolecodontes. Review of Palaeobotany and Palynology 13(3-4), 233-252. DOI 10.1016/0034-6667(72)90033-4

Taugourdeau, P. \& Iliescu, V. 1983. Quelques Scolecodontes disperses du Silurien de Roumanie. Comptes Rendus du Congres National des Societes Savantes, Sciences de la Terre 107(3), 9-21.

TonarovÁ, P. 2008. Revision of Kettnerites Žebera, 1935 (Scolecodonta, Silurian of the Barrandian area, Czech Republic): preliminary results. Acta Musei Nationalis Prague, Series B - historia naturalis 64(2-4), 185-192.

Torsvik, T.H., Smethurst, M.A., Van DE Voo, R., Trench, A., Brahamsen, N. \& Halvorsen, E. 1992. Baltica. A synopsis of Vendian-Permian palaeomagnetic data and their palaeotectonic implications. Earth-Science Reviews 33, 133-152. DOI 10.1016/0012-8252(92)90023-M

TUREK, V. \& MANDA, Š. 2011. Colour pattern polymorphism in Silurian nautiloid Phragmoceras Broderip, 1839. Bulletin of Geosciences 86(1), 91-105. DOI 10.3140/bull.geosci.1240

UrbaneK, A. 1993. Biotic crises in the history of upper Silurian graptoloids: a palaeobiological model. Historical Biology 7, 29-50. DOI 10.1080/10292389309380442

Williams, H.S., Nowlan, G.S., Barnes, C.R. \& Batten, R.S.R. 1999. The Ledge section at Cow Head, western Newfoundland as a GSSP candidate for the lower boundary of the second stage of the Ordovician System: new data and discussion of the graptolite, conodont and chitinozoan assemblages. A Report to the IUGS/ICS Subcommision on Ordovician Stratigraphy, June 1999, 1-30.

Žebera, K. 1935. Les Conodontes et les Scolécodontes du Barrandien. Bulletin international de l'Académie des Sciences de Bohême 45(22), 1-20. 